\section{Nipah and Hendra Virus Nucleoproteins Inhibit Nuclear Accumulation of Signal Transducer and Activator of Transcription 1 (STAT1) and STAT2 by Interfering with Their Complex Formation}

\author{
Akihiro Sugai, Hiroki Sato, Ikuyo Takayama,* Misako Yoneda, Chieko Kai \\ Laboratory Animal Research Center, The Institute of Medical Science, The University of Tokyo, Tokyo, Japan
}

ABSTRACT Henipaviruses, such as Nipah (NiV) and Hendra (HeV) viruses, are highly pathogenic zoonotic agents within the Paramyxoviridae family. The phosphoprotein (P) gene products of the paramyxoviruses have been well characterized for their interferon (IFN) antagonist activity and their contribution to viral pathogenicity. In this study, we demonstrated that the nucleoprotein $(\mathrm{N})$ of henipaviruses also prevents the host IFN signaling response. Reporter assays demonstrated that the NiV and HeV $\mathrm{N}$ proteins (NiV-N and HeV-N, respectively) dose-dependently suppressed both type I and type II IFN responses and that the inhibitory effect was mediated by their core domains. Additionally, NiV-N prevented the nuclear transport of signal transducer and activator of transcription 1 (STAT1) and STAT2. However, NiV-N did not associate with $\operatorname{Imp} \alpha 5, \operatorname{Imp} \beta 1$, or Ran, which are members of the nuclear transport system for STATs. Although $\mathrm{P}$ protein is known as a binding partner of $\mathrm{N}$ protein and actively retains $\mathrm{N}$ protein in the cytoplasm, the IFN antagonist activity of $\mathrm{N}$ protein was not abolished by the coexpression of $\mathrm{P}$ protein. This suggests that the IFN inhibition by $\mathrm{N}$ protein occurs in the cytoplasm. Furthermore, we demonstrated that the complex formation of STATs was hampered in the $\mathrm{N}$ protein-expressing cells. As a result, STAT nuclear accumulation was reduced, causing a subsequent downregulation of interferon-stimulated genes (ISGs) due to low promoter occupancy by STAT complexes. This novel route for preventing host IFN responses by henipavirus $\mathrm{N}$ proteins provides new insight into the pathogenesis of these viruses.

IMPORTANCE Paramyxoviruses are well known for suppressing interferon (IFN)mediated innate immunity with their phosphoprotein $(P)$ gene products, and the henipaviruses also possess $\mathrm{P}, \mathrm{V}, \mathrm{W}$, and $\mathrm{C}$ proteins for evading host antiviral responses. There are numerous studies providing evidence for the relationship between viral pathogenicity and antagonistic activities against IFN responses by $P$ gene products. Meanwhile, little attention has been paid to the influence of nucleoprotein $(\mathrm{N})$ on host innate immune responses. In this study, we demonstrated that both the NiV and HeV N proteins have antagonistic activity against the JAK/STAT signaling pathway by preventing the nucleocytoplasmic trafficking of STAT1 and STAT2. This inhibitory effect is due to an impairment of the ability of STATs to form complexes. These results provide new insight into the involvement of $\mathrm{N}$ protein in viral pathogenicity via its IFN antagonism.
Received 6 July 2017 Accepted 16 August 2017

Accepted manuscript posted online 23 August 2017

Citation Sugai A, Sato H, Takayama I, Yoneda M, Kai C. 2017. Nipah and Hendra virus nucleoproteins inhibit nuclear accumulation of signal transducer and activator of transcription 1 (STAT1) and STAT2 by interfering with their complex formation. J Virol 91:e01136-17. https://doi.org/10.1128/JVI.01136-17. Editor Terence S. Dermody, University of Pittsburgh School of Medicine

Copyright $\odot 2017$ American Society for Microbiology. All Rights Reserved.

Address correspondence to Chieko Kai, ckai@ims.u-tokyo.ac.jp.

* Present address: Ikuyo Takayama, Influenza Virus Research Center, National Institute of Infectious Diseases, Tokyo, Japan. 
$\mathrm{N}$ pah virus (NiV), a virus of the genus Henipavirus within the Paramyxoviridae family, is an emerging zoonotic pathogen that was first isolated in 1999 during an outbreak in Malaysia (1). NiV outbreaks have been reported sporadically in Malaysia, Singapore, Bangladesh, and India, with a 40 to $90 \%$ fatality rate $(2,3)$. Some serological surveys revealed that NiV has a wide host range, including humans, pigs, dogs, cats, horses, goats, hamsters, and fruit bats (4-6). The main clinical feature of human NiV infection is severe febrile encephalitis with a high mortality rate, which is a leading cause of fatal cases of NiV infection (7). In Bangladesh, more than half of the reported cases were due to human-to-human transmission (8-12). NiV is closely related to Hendra virus (HeV), which is also an emerging fatal Henipavirus species (13). The case fatality rate of $\mathrm{HeV}$ infection in humans has been reported to be around $60 \%$ (14), and as with NiV infection, encephalitis is an important cause of fatal cases of HeV infection in humans (15).

NiV has a nonsegmented negative-sense single-stranded RNA genome that encodes six structural proteins, namely, N, P, M, F, G, and L, corresponding to nucleoprotein, phosphoprotein, matrix protein, fusion protein, glycoprotein, and large protein, respectively $(5,13)$. The $\mathrm{P}$ gene also produces three accessory proteins, known as $\mathrm{V}, \mathrm{W}$, and $C$ (16). The $V$ and $W$ proteins are generated by site-specific mRNA editing during viral transcription; a nontemplated one and two $\mathrm{G}$ nucleotides, respectively, are inserted at the editing site $(1,17)$. The mRNA for the $C$ protein is transcribed from an alternative open reading frame within the $P$ gene (1).

Virus infection typically activates host innate immunity, including the interferon (IFN) signaling pathway, and IFN responses during virus infection have been well studied. Type I IFNs (IFN- $\alpha$ and IFN- $\beta$ ) induce phosphorylation of tyrosine kinase 2 and Janus kinase 1 (JAK1), and these kinases activate signal transducer and activator of transcription 1 (STAT1) and STAT2 via phosphorylation at the tyrosine residues (18-20). Phosphorylated STAT1 and STAT2 form a heterodimer $(21,22)$. STAT2 is constitutively associated with IFN regulatory factor 9 (IRF9), and the STAT1/STAT2/IRF9 transcription factor complex is called IFN-stimulated gene factor 3 (ISGF3) $(23,24)$. Subsequently, the ISGF3 complex is imported into the nucleus by the nuclear import receptors importin $\alpha 5$ (Imp $\alpha 5)$ and importin $\beta 1(\operatorname{Imp} \beta 1)$ (25). In the nucleus, ISGF3 is released from Imp $\alpha 5$ by the binding of Ran-GTP to $\operatorname{Imp} \beta 1$ (26), and it subsequently binds to a promoter site, the IFN-stimulated response element (ISRE), to regulate the transcription of IFNstimulated genes (ISGs). Likewise, type II IFN (IFN- $\gamma$ ) induces the phosphorylation of STAT1, which forms a homodimer. The STAT1 homodimer translocates to the nucleus and binds to the gamma interferon activation site (GAS) to induce gamma-inducible genes (27). Dephosphorylation of the STATs by protein tyrosine phosphatase (PTPase) causes the dissociation of STAT dimers, after which STAT1 and STAT2 return to their inactive forms (28).

It has been reported that $\mathrm{P}$ gene products within paramyxoviruses inhibit host IFN responses via various mechanisms; for instance, they bind to the signal transducer of the IFN pathway and prevent its activation and translocation (16, 29-31). Meanwhile, we recently found that the $\mathrm{N}$ protein of measles virus (MV-N), which belongs to the Morbillivirus genus within the Paramyxoviridae family, inhibits host IFN responses by disrupting the JAK/STAT signaling pathway (32). It was demonstrated that the MV-N protein possesses a nuclear localization signal (NLS) that is a leucine/isoleucine-rich motif within the N-terminal region (amino acids at positions 70 to 77) (33). The MV-N protein is distributed throughout the whole cell and forms intranuclear inclusion bodies. Our previous study revealed that the IFN antagonist activity of the MV-N protein requires its own nuclear translocation (32). Henipaviruses are phylogenetically related to the morbilliviruses, and the NiV-N protein also makes inclusion bodies in the nucleus; therefore, we evaluated the IFN antagonist activity of henipavirus $\mathrm{N}$ proteins. In the present study, we assessed if the NiV and HeV N proteins also exhibit this novel function for suppressing host IFN responses, and we further investigated the mechanism by which the henipavirus $N$ proteins inhibit the host JAK/STAT pathway. 


\section{RESULTS}

Suppression of type I and II IFN responses by henipavirus $\mathbf{N}$ proteins. To evaluate if the NiV-N and HeV-N proteins can inhibit host IFN responses as well as the MV-N protein does (32), we conducted reporter gene assays. The expression of both ISRE- and GAS-driven reporter genes was inhibited by henipavirus $\mathrm{N}$ proteins in a dose-dependent manner (Fig. 1A). We then compared the IFN antagonism of the $\mathrm{N}$ protein (NiV-N, HeV-N, and MV-N) to that of the P gene products ( $\mathrm{P}, \mathrm{V}$, and $\mathrm{W}$ ). All the $\mathrm{N}, \mathrm{P}, \mathrm{V}$, and $\mathrm{W}$ proteins significantly suppressed type I and type II IFN responses. The N protein showed lower antagonist activity for type I IFN than that of the $P$ gene products, but it downregulated type II IFN responses as well as the P gene products did (Fig. 1B). Although $\mathrm{P}$ protein is a major binding partner of $\mathrm{N}$ protein (34), the coexpression of $\mathrm{N}$ and $\mathrm{P}$ proteins did not reduce their IFN antagonist activity (Fig. 1B). The expression levels of the IFN antagonists were evaluated by immunoblotting (Fig. 1C). We used protein-specific antibodies to detect untagged $\mathrm{N}$ and $\mathrm{P}$ proteins. To enable a comparison of these protein levels, identical volumes of myc-tagged MV-N, HeV-N, NiV-N, and NiV-P proteins were detected by both protein-specific antibodies and an anti-myc antibody (Fig. 1D).

It has been reported that paramyxovirus $\mathrm{N}$ proteins consist of two major domains: a highly structured core domain and a disordered tail domain (35-39). We next examined which domains were responsible for preventing the IFN- $\alpha$ and $-\gamma$ responses. Plasmids for the core domain (amino acids [aa] 1 to 400) and the tail domain (aa 401 to 532) of the NiV-N and HeV-N proteins were transfected into cells with reporter plasmids, and the luciferase activity was measured after IFN- $\alpha$ or $-\gamma$ stimulation. In the presence of the core domain of the NiV-N or HeV-N protein, both the IFN- $\alpha$ and $-\gamma$ responses were significantly suppressed (Fig. 1E). In contrast, the tail domains of these henipavirus $\mathrm{N}$ proteins failed to prevent the IFN responses. The expression of $\mathrm{N}$-core and $\mathrm{N}$-tail was confirmed by immunoblot assays (Fig. 1F). To identify the location where the henipavirus $\mathrm{N}$ protein hampers the IFN signaling pathway, we investigated the localization of full-length NiV-N protein and its core domain by immunofluorescence assays. In Cos7 cells, the transiently expressed NiV-N protein or its core domain accumulated in both the cytoplasmic and nuclear compartments, and the immunoreactive aggregates were detected throughout the whole cell (Fig. 1G). Additionally, the tail domain of the NiV-N protein diffused throughout the cell. The NiV-N protein can therefore potentially affect any step of the IFN signal transduction pathway (40).

NiV-N interrupts nuclear accumulation of STATs. To narrow the list of candidates for the target molecule of NiV-N, we examined if the nucleocytoplasmic transport of STAT1 was affected by the NiV-N protein. Since STAT1 is known to constantly shuttle between the nucleus and the cytoplasm (41), STAT1 is normally detected throughout the whole cell. In contrast, after IFN- $\alpha$ or $-\gamma$ stimulation, STAT1 molecules are predominantly detected in the nuclear compartment. In the presence of $\mathrm{N}$ protein, however, STAT1 was detected in both the nucleus and the cytoplasm, regardless of IFN stimulation (Fig. 2). Similarly, in the presence of $N$ protein, STAT2 also tended to be distributed throughout the whole cell after IFN- $\alpha$ stimulation (Fig. 2). We next investigated the localization of phospho-STAT1 (pSTAT1) and phospho-STAT2 (pSTAT2) in the $\mathrm{N}$ protein-expressing cells. Nuclear translocation of PSTAT1 and pSTAT2 after IFN stimulation was also inhibited by $\mathrm{N}$ protein expression (Fig. 2). In this study, the distribution of STAT1 and pSTAT2 was examined in Cos7 cells, and that of pSTAT1 and STAT2 was examined in HeLa cells, according to the reactivity of the specific antibodies. For a statistical evaluation of their localization, we scored the distribution of the STATs after IFN- $\alpha$ or $-\gamma$ stimulation. In the NiV-N-expressing cells, nuclear accumulation of STAT1, pSTAT1, STAT2, and PSTAT2 was each significantly interrupted (Fig. 2).

Investigation of potential NiV-N target molecules. The STATs require association with Imp $\alpha 5$, and possibly also Imp $\alpha 6$ and -7 , to translocate into the nucleus (42). We investigated if NiV-N interrupts the interaction between STAT1 and Imp $\alpha 5$, Imp $\alpha 6$, or Imp $\alpha 7$. Regardless of the presence or absence of NiV-N, coprecipitations of PSTAT1 with 

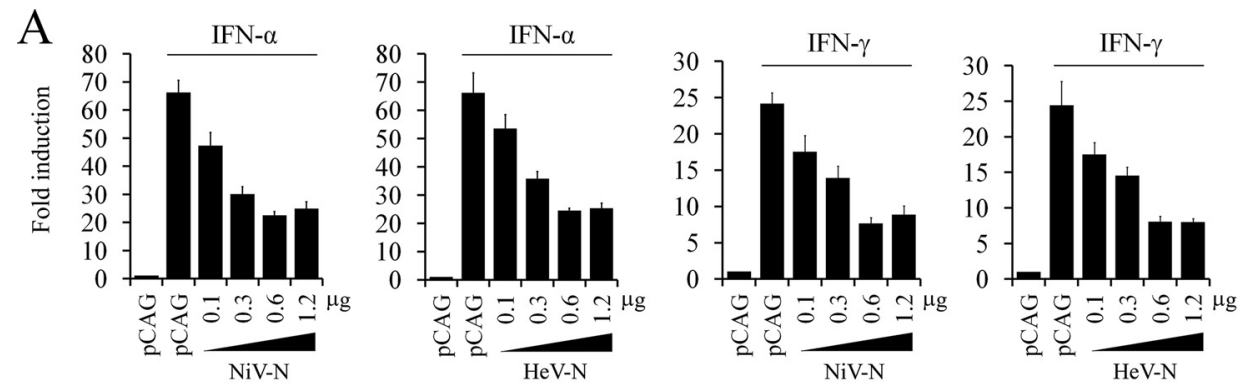

B
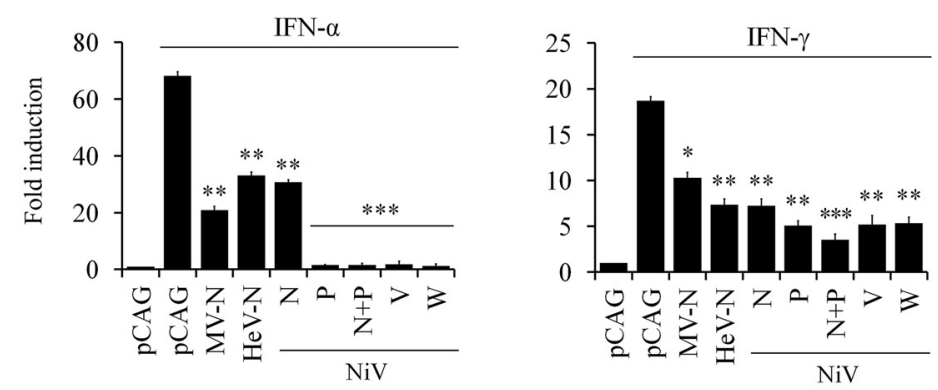

$\mathrm{C}$
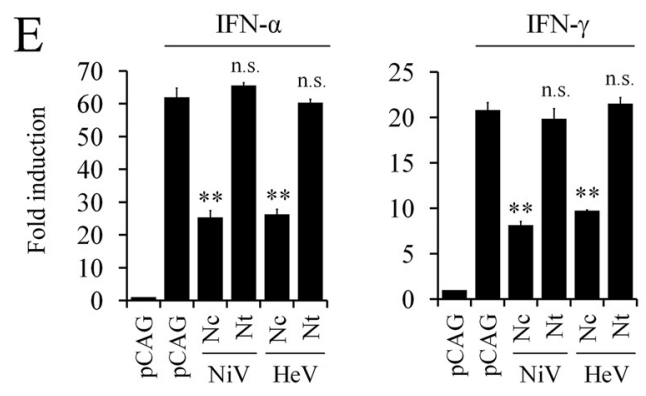

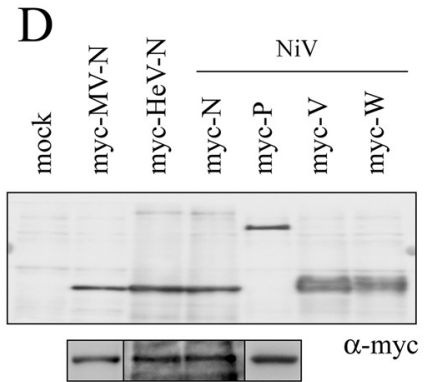

$\alpha-\mathrm{MV}-\mathrm{N} \quad \alpha-\mathrm{NiV}-\mathrm{N} \quad \alpha-\mathrm{NiV}-\mathrm{P}$
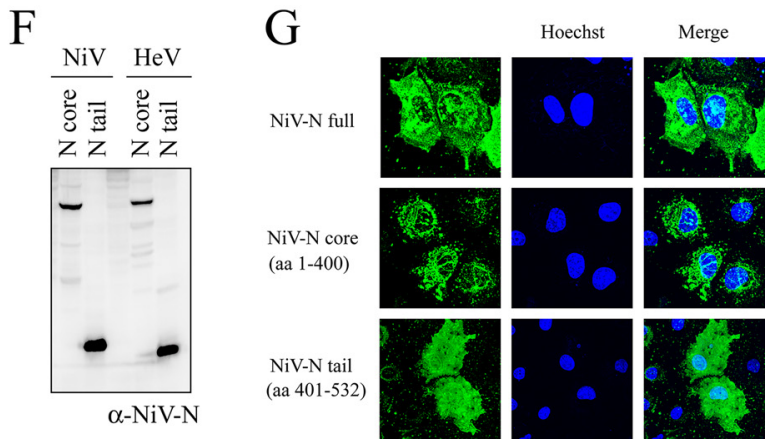

FIG 1 Type I and II IFN responses in the presence or absence of henipavirus $N$ protein. (A) pISRE-Luc and pGAS-Luc reporter gene assays with various concentrations of pCAGGS-NiV-N or -HeV-N plasmid $(0.1,0.3,0.6$, and $1.2 \mu \mathrm{g})$ after IFN- $\alpha$ or $-\gamma$ stimulation in 293T cells. The transfection volume of DNA (pCAGGS-NiV-N [or -HeV-N] and the pCAGGS empty vector) was adjusted to a total of $1.2 \mu \mathrm{g}$. The phRL-TK (Int-) vector was cotransfected as a control for transfection efficiency. IFN responses are shown as relative luc activities compared to the Rluc activity from the control vector. Error bars indicate standard deviations. (B) 293T cells were transfected with reporter plasmids, phRL-TK (Int-), and pCAGGS-MV-N, -HeV-N, -NiV-N, or -NiV-P or pCMV-myc-NiV-V or -NiV-W. At $24 \mathrm{~h}$ posttransfection, reporter assays were conducted. Error bars indicate standard deviations. $P$ values were calculated by two-tailed Student's $t$ test. ${ }^{*}, P<$ $0.05 ;{ }^{* *}, P<0.01 ;{ }^{* * *}, P<0.001$. (C) The expression of each antagonist in the lysates was verified by Western blot analysis using a specific antibody ( $\alpha$-MV-N, $\alpha$-NiV-N, or $\alpha$-NiV-P) or an anti-myc rabbit polyclonal antibody ( $\alpha$-myc). The experiment was repeated three times, and a representative blot is shown. (D) 293T cells were transfected with pCMV-myc-MV-N, -HeV-N, -NiV-N, -NiV-P, -NiV-V, or -NiV-W or with empty vector, and the expression of each antagonist was detected with a specific antibody and an anti-myc rabbit polyclonal antibody. The experiment was repeated twice independently. (E) 293T cells were transfected with an expression plasmid for the $\mathrm{N}$ protein core domain $(\mathrm{Nc}$ ) or tail domain (Nt) of NiV or HeV, followed by stimulation with $1,000 \mathrm{U} / \mathrm{ml} \mathrm{IFN-} \alpha$ or $-\gamma$, and the IFN responses were measured by reporter assays as described above. Error bars indicate standard deviations. ${ }^{* *}, P<0.01$; n.s., not significant. (F) Expression levels of NiV-Nc, NiV-Nt, HeV-Nc, and HeV-Nt in 293T cells. The experiment was conducted three times, and a representative blot is shown. (G) Z-stack images showing the distribution of NiV-N, -Nc, and -Nt in Cos7 cells stained using an anti-NiV-N polyclonal antibody. 
Cos7 cells
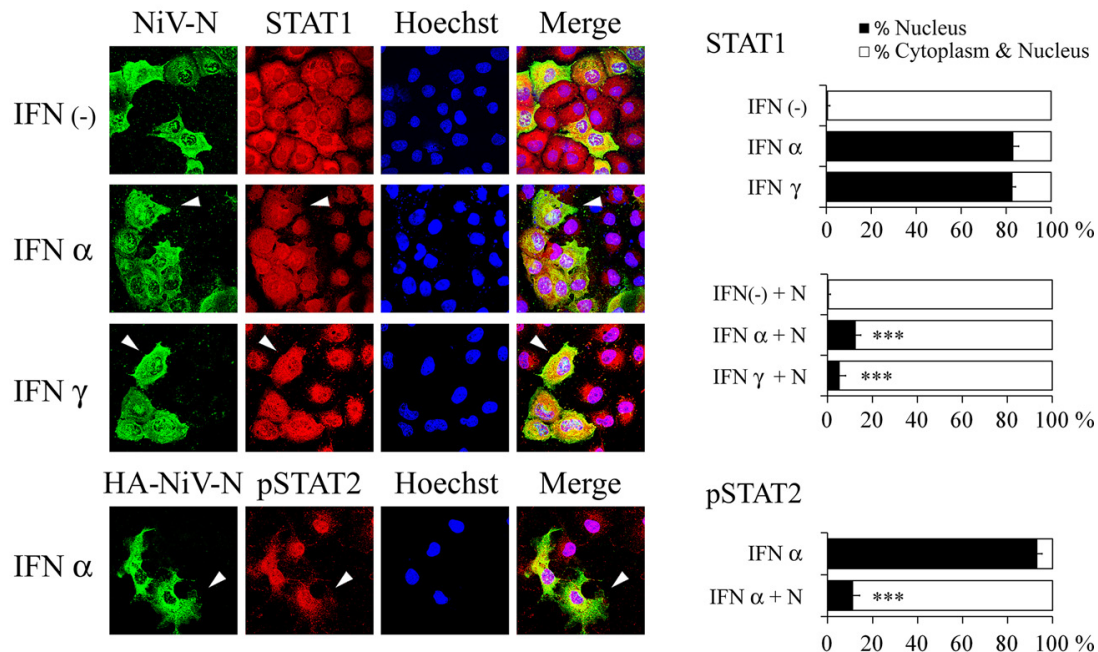

HeLa cells

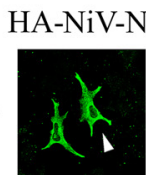

IFN $\gamma$
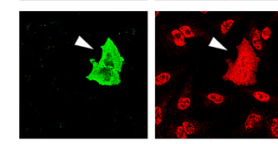

HA-NiV-N STAT2
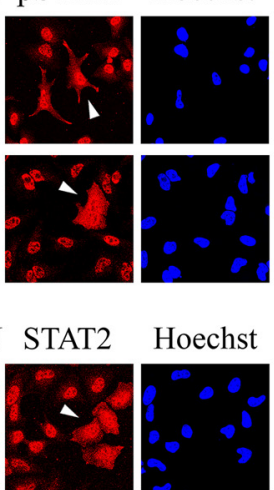

Merge

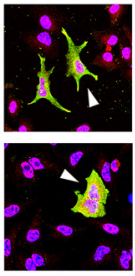

Merge

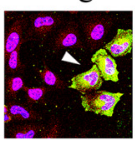

pSTAT1
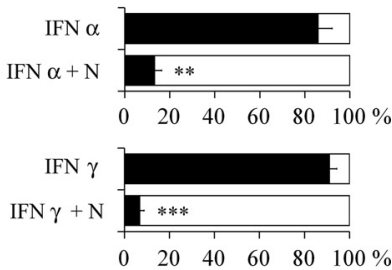

STAT2

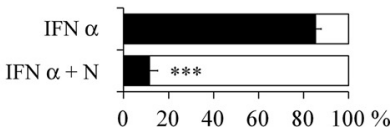

FIG 2 Inhibition of nuclear accumulation of STAT1 and -2 in the presence of NiV-N protein. (A) Cos7 or HeLa cells were transfected with $0.6 \mu \mathrm{g}$ of the PCAGGS-NiV-N or -NiV-N-HA expression plasmid and were treated with IFN- $\alpha$ or $-\gamma$ for $30 \mathrm{~min}$. The cells were stained using anti-STAT1, -pSTAT1, -STAT2, and -pSTAT2 antibodies with an anti-N polyclonal antibody (or anti-HA mouse antibody) and Hoechst 33342 dye. The images shown are all z-stack data. Arrowheads indicate the cytoplasmic STATs in the NiV-Nexpressing cells. The bar graphs show the statistical evaluation of STAT nuclear accumulation. We compared the scores for STAT distribution between NiV-N-expressing and non-NiV-N-expressing cells. The scores were calculated by counting approximately 60 cells from at least five randomly selected fields. Filled bars indicate the percentage of nuclear localization, while white bars indicate the percentage of whole-cell distribution. Error bars indicate standard deviations. The experiments were repeated three times independently. ${ }^{* *}, P<0.01 ;{ }^{* * *}, P<0.001$.

Imp $\alpha 5$, Imp $\alpha 6$, and $\operatorname{Imp} \alpha 7$ were not changed (Fig. 3A). Additionally, NiV-N did not prevent the phosphorylation of STAT1. NiV-P was used as a control because it acted as an inhibitor of STAT1-Imp $\alpha 5$ binding $(27,29)$. Since Imp $\alpha 1$ does not interact with STAT1 $(43,44)$, it was used as a negative control which does not coprecipitate with STAT1. We also investigated the binding of NiV-N to $\operatorname{Imp} \beta 1$ and Ran. $\operatorname{Imp} \beta 1$ associates with $\operatorname{Imp} \alpha 5$ to facilitate its translocation through the nuclear pore complex $(45,46)$. Ran continuously shuttles between the nucleus and the cytoplasm to control the binding and release of cargo molecules $(47,48)$. Hemagglutinin $(H A)$-tagged Imp $\beta 1$ or Ran was expressed with the NiV-N protein in 293T cells, and coprecipitation assays were performed using anti-HA and anti-N antibodies. Although $\operatorname{Imp} \beta 1$ and Ran coprecipitated with the positive controls, i.e., $\operatorname{Imp} \alpha 5$ and $\operatorname{Imp} \beta 1$, respectively, they both failed to coprecipitate NiV-N (Fig. 3B). Moreover, the binding ability of NiV-N for STAT1, STAT2, 

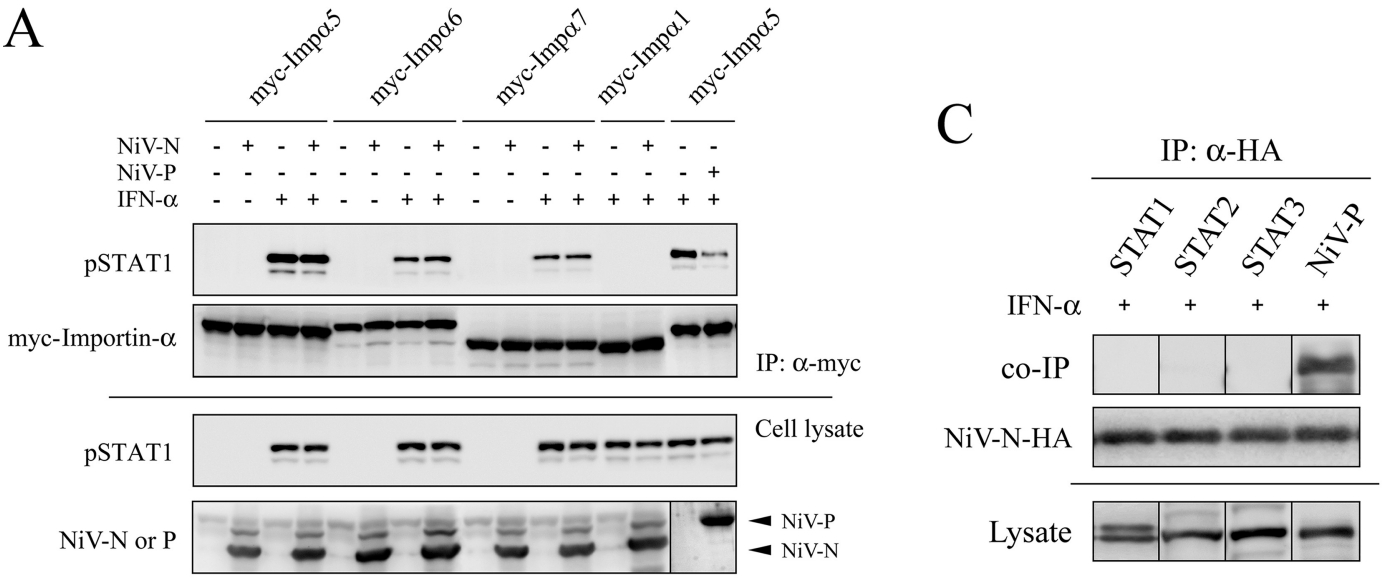

B
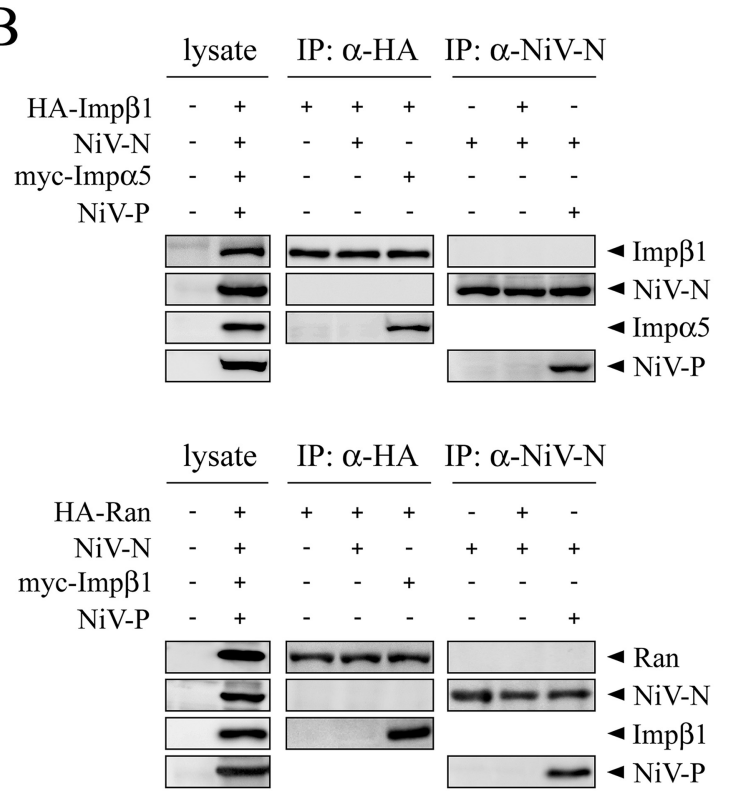

IP: $\alpha-N i V-N$

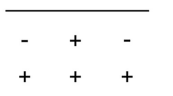

$\mathrm{E}$

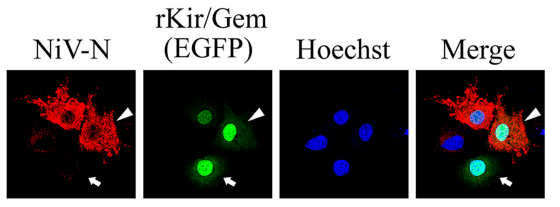

D Fold induction
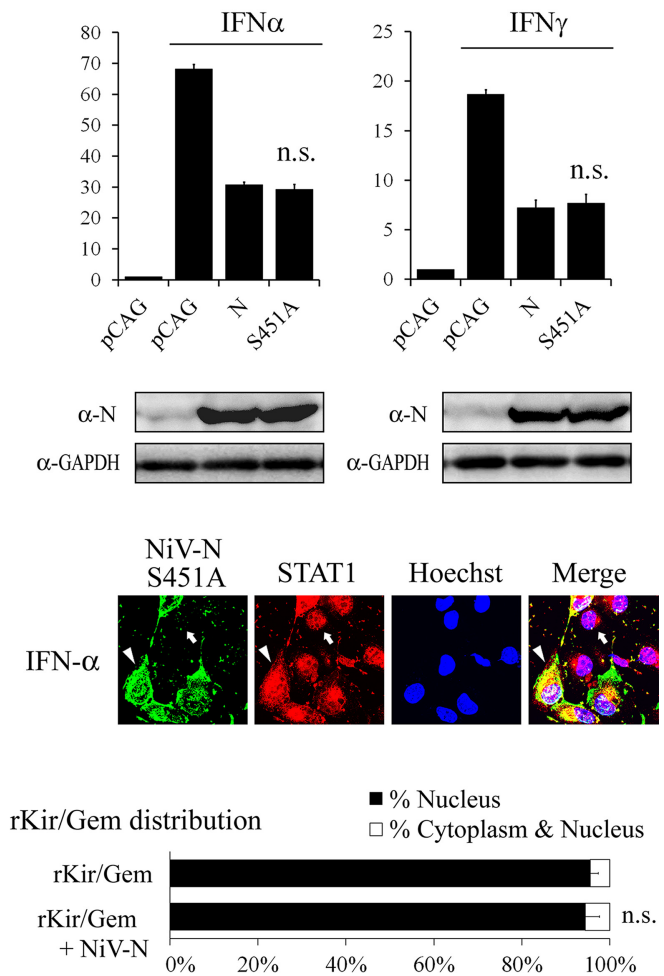

FIG 3 Influence of NiV-N on the STAT nuclear import system. (A) The associations between STAT1 and Imp $\alpha 5$, Imp $\alpha 6$, and Imp $\alpha 7$ in the presence of $\mathrm{N}$ protein were evaluated by immunoprecipitation (IP). The myc-tagged importins were precipitated with an anti-myc antibody, and the coprecipitation of pSTAT1 with $\operatorname{Imp} \alpha 5$, Imp $\alpha 6$, or $\operatorname{Imp} \alpha 7$ was evaluated in the presence or absence of $\mathrm{N}$ protein. A myc-tagged Imp $\alpha 1$ construct was employed as a negative control. $\mathrm{P}$ protein served as a positive-control antagonist of the interaction between Imp $\alpha 5$ and STAT1. (B) The interaction between NiV-N and HA-Imp $\beta 1$ or HA-Ran was investigated with immunoprecipitation assays using anti-HA and anti-NiV-N antibodies. The myc-Imp $\alpha 5$, myc-Imp $\beta 1$, and NiV-P proteins were included as positive controls for immunoprecipitation. (C) 293T cells were transfected with pCAGGS-NiV-N (encoding a C-terminal HA tag). After $24 \mathrm{~h}$, the cells were treated with 1,000 U/ml IFN- $\alpha$ for 30 min, and immunoprecipitation was conducted using anti-HA antibody. STAT1, STAT2, STAT3, and N protein in the lysates were detected with anti-STAT1 (E-23), -2 (C-20), and $-3(\mathrm{H}-190)$ and anti-N protein antibodies, respectively. The $\mathrm{P}$ protein served as a positive control for an $\mathrm{N}$-binding protein. For panels $A$ to $C$, the experiments were independently repeated three times, and representative blots are displayed. (D) A reporter assay was conducted using $293 \mathrm{~T}$ cells transfected with the NiV-N or N-S451A plasmid. The expression levels of each $\mathrm{N}$ protein and GAPDH are shown. Error bars indicate standard deviations. n.s., not significant. N-S451A-expressing Cos7 cells were treated with $2,000 \mathrm{U} / \mathrm{ml}$ of IFN- $\alpha$. N-S451A and STAT1 were detected with specific antibodies and are shown as z-stack immunofluorescence images. Arrowheads and arrows indicate an N-S451A-expressing and a non-N-S451A-expressing cell, respectively. The experiment was independently conducted three times. (E) The expression plasmids for NiV-N and EGFP-Kir/Gem-W268G (referred to here as $\mathrm{rKir} / \mathrm{Gem}$ ) were transfected into Cos7 cells, and NiV-N was detected with an anti-NiV-N polyclonal antibody. The nuclei were stained with Hoechst dye. Images shown are z-stack data. The arrowheads and arrows point to a NiV-N-expressing and a non-NiV-Nexpressing cell, respectively. The bar graph indicates the statistical evaluation of the rKir/Gem distribution. The scores were determined by counting approximately 60 cells from five randomly selected fields. n.s., not significant. 
and STAT3 was each examined after treatment with IFN- $\alpha$. However, no binding between $\mathrm{N}$ protein and any of the STATs was detected (Fig. 3C).

Our previous study identified the phosphorylation site of NiV-N as Ser-451 (49). We investigated the influence of $\mathrm{N}$ protein phosphorylation on the IFN antagonist activity by using an S451A alanine substitution mutant. In the reporter assay, there was no difference in the suppression of the IFN- $\alpha$ or $-\gamma$ response between wild-type $\mathrm{N}$ (wt-N) and the S451A mutant (Fig. 3D). The S451A mutant inhibited the nuclear translocation of STAT1 in IFN- $\alpha$-stimulated cells as efficiently as the intact $\mathrm{N}$ protein did (Fig. 3D). Thus, phosphorylation at Ser-451 of the $\mathrm{N}$ protein is not involved in the prevention of the IFN response. Kir/Gem, a small G protein, has been reported to be imported by Imp $\alpha 5$ (50). We examined if NiV-N also interfered with the nuclear translocation of Kir/Gem-W268G (the W268G substitution prevents the association between Kir/Gem and calmodulin, which retains Kir/Gem in the cytoplasm [50]). Transiently expressed Kir/Gem-W268G showed nuclear localization, and its localization was not significantly affected by the expression of NiV-N (Fig. 3E).

NiV-N inhibits nuclear import by hampering STAT complex formation in the cytoplasm. Nuclear export of STAT2 is selectively mediated by CRM1, which is also known as exportin-1 $(25,51)$. STAT2 constitutively shuttles between the nucleus and the cytoplasm $(25,27)$, so when STAT2 nuclear export is blocked in the presence of the CRM1 inhibitor leptomycin B (LMB), STAT2 gradually accumulates in the nucleus (52). As expected, after only $1 \mathrm{~h}$ of treatment with $20 \mathrm{nM}$ LMB, STAT2 was distributed in the whole cell; however, after $16 \mathrm{~h}$ of this treatment, STAT2 accumulated in the nucleus (Fig. 4A). To clarify if the inhibition of STAT nuclear accumulation by $\mathrm{N}$ protein was due to import prevention or export acceleration, we evaluated the localization of STAT2 in NiV-N-expressing cells after LMB and IFN- $\alpha$ treatment. We treated N protein-expressing HeLa cells with $20 \mathrm{nM}$ LMB for $30 \mathrm{~min}$, and STAT2 did not accumulate in the nucleus at this stage (Fig. 4A). Subsequently, the cells were simultaneously treated with $20 \mathrm{nM}$ LMB and IFN- $\alpha$ for 30 min. We observed a suppression of STAT2 nuclear accumulation after IFN- $\alpha$ stimulation by NiV-N in these LMB-treated cells (Fig. 4B), suggesting that $\mathrm{N}$ protein does not enhance export but rather interferes with STAT import. Localization of the $\mathrm{N}$ protein was not affected by LMB treatment (Fig. 4B).

The $\mathrm{P}$ protein binds to the $\mathrm{N}$ protein and retains the $\mathrm{N}$ protein in the cytoplasm ( 34 , 53). To evaluate the influence of $N$ and $P$ protein interaction on the inhibition of IFN signaling by $\mathrm{N}$ protein, we conducted reporter assays in the presence of a $\mathrm{P}$ protein mutant that has a $\mathrm{G} 125 \mathrm{E}$ substitution $(\mathrm{mP})$. This substitution in the $\mathrm{P}$ protein disables the association between the P protein and STAT1 (29). Coexpression of the MP protein did not affect the IFN antagonist activity of $\mathrm{N}$ protein (Fig. 4C), although $\mathrm{mP}$ showed an intact binding ability with $\mathrm{N}$ protein in an immunoprecipitation assay (Fig. 4D) and was able to retain $\mathrm{N}$ protein in the cytoplasm, as demonstrated by the results of an immunofluorescence assay (Fig. 4E). Thus, the association between the $\mathrm{N}$ and $\mathrm{P}$ proteins did not appear to interfere with the IFN antagonist activity of $\mathrm{N}$ protein, and this finding also suggests that the inhibition of IFN signaling occurs in the cytoplasm.

To examine the influence of NiV-N on STAT dimerization, we detected STAT complexes in the presence or absence of the $\mathrm{N}$ protein by blue native PAGE (BN-PAGE). In both the IFN- $\alpha$ - and IFN- $\gamma$-stimulated cells, those expressing the $\mathrm{N}$ protein showed a notable impairment in STAT1 complex formation (Fig. 4F). In each case, the expression of $\mathrm{N}$ protein did not cause a mobility shift of the STAT1 complex bands, suggesting that NiV-N did not bind to the complex. Also, the anti-N protein antibody did not detect the STAT1 complex in the BN-PAGE gel (Fig. 4F). The expression levels of pSTAT1, STAT1, NiV-N, and GAPDH in each cell lysate were measured by SDS-PAGE (Fig. 4G). Thus, the $\mathrm{N}$ protein inhibited the complex formation of STAT1 without directly binding to the complex.

Suppression of ISGs by $\mathbf{N}$ protein. We investigated if the inhibition of STAT complex formation by $\mathrm{N}$ protein reduces the nuclear PSTAT1 level. To quantify the nuclear PSTAT1 level after IFN stimulation, we fractionated the cytoplasmic and nuclear 
A

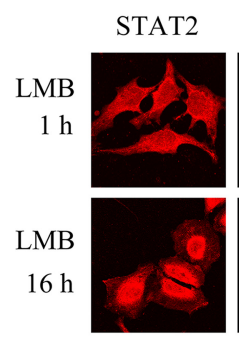

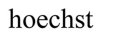
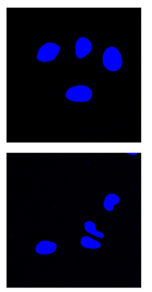

merge

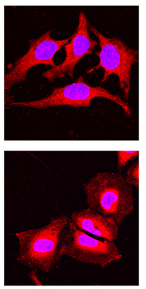

B

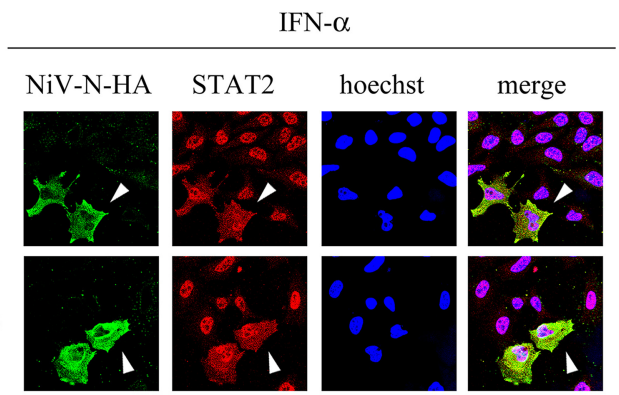

C

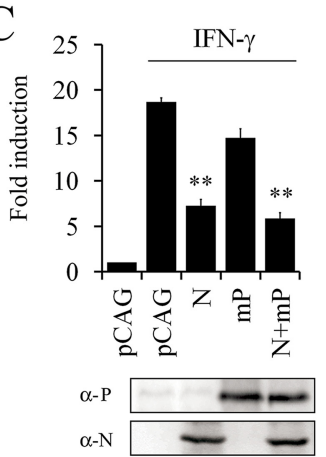

$\mathrm{D}$

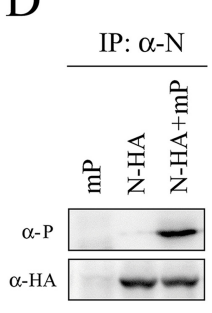

F

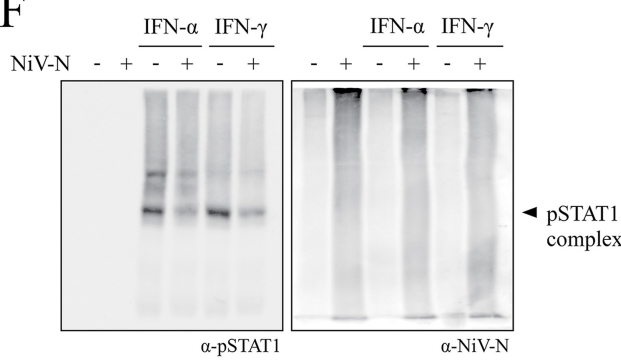

G

E

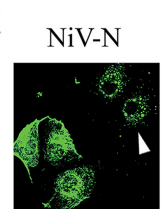

$\mathrm{mP}$

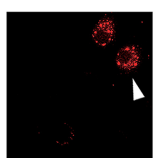

Hoechst

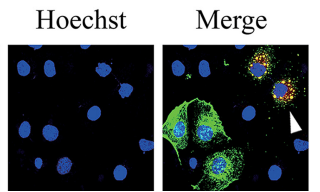

FIG 4 Analysis of the mechanism by which NiV-N prevents STAT nuclear accumulation. (A) HeLa cells were treated with $20 \mathrm{nM} \mathrm{LMB}$ at $37^{\circ} \mathrm{C}$ for $1 \mathrm{~h}$ or $16 \mathrm{~h}$, and STAT2 was detected by use of an anti-STAT2 polyclonal antibody (C-20). (B) HeLa cells were transfected with a NiV-N expression vector. At $24 \mathrm{~h}$ posttransfection, the cells were left untreated or treated with $20 \mathrm{nM} \mathrm{LMB}$ at $37^{\circ} \mathrm{C}$ for $1 \mathrm{~h}$. After treatment with $1,000 \mathrm{U} / \mathrm{ml}$ IFN- $\alpha$, the localization of STAT2 and N protein was investigated by use of anti-STAT2 (C-20) and anti-N protein antibodies. Arrowheads indicate cytoplasmic STAT2 in a NiV-N-expressing cell. Images shown are z-stack data. The experiment was repeated three times independently. (C) 293T cells transfected with the pGAS-Luc plasmid and the pCAGGS-NiV-N or $-\mathrm{mP}$ plasmid were treated with $1,000 \mathrm{U} / \mathrm{ml}$ IFN- $\gamma$, and the reporter gene activity was measured. ${ }^{* *}, P<0.01$. The expression of each protein in the cell lysates was verified by Western blot analysis. The experiment was independently repeated three times in triplicate. (D) 293T cells were transfected with pCAGGS-NiV-N (encoding a C-terminal HA tag) and -mP, and immunoprecipitation was conducted twice independently with an anti-N protein antibody. (E) The colocalization of N protein with $\mathrm{mP}$ (with an N-terminal HA tag) in the cytoplasm was evaluated using immunofluorescence assays. These proteins were detected by use of anti-N protein and anti-HA antibodies, respectively. Arrowheads indicate the cytoplasmic colocalization of $\mathrm{N}$ and $\mathrm{mP}$. Z-stack images are represented. (F) NiV-N expression plasmid-transfected or untransfected 293T cells were treated with $1,000 \mathrm{U} / \mathrm{ml}$ IFN- $\alpha$ or IFN- $\gamma$ for $20 \mathrm{~min}$. The cells were fixed with $20 \mathrm{mM}$ dimethyl suberimidate for $30 \mathrm{~min}$ and then lysed for $15 \mathrm{~min}$. The cell lysates were immediately subjected to BN-PAGE. STAT1 complexes were detected by use of an anti-pSTAT1 antibody. The association between STAT1 complexes and the NiV-N protein was examined using an anti-N protein-specific antibody. (G) STAT1, pSTAT1, NiV-N, and GAPDH in the cell lysates were detected by SDS-PAGE. For panels $\mathrm{F}$ and $\mathrm{G}$, the experiments were repeated three times, and representative data are displayed.

proteins and evaluated the influence of NiV-N on the level of nuclear pSTAT1 by immunoblotting. In the presence of $\mathrm{N}$ protein, almost no change was detected in the cytoplasmic or whole-cell pSTAT1 level; in contrast, the nuclear pSTAT1 level was reduced in the $\mathrm{N}$ protein-expressing cells (Fig. 5A). We measured nuclear pSTAT1 levels by densitometric analysis in three independent experiments and demonstrated significant reductions of nuclear pSTAT1 levels in the N protein-expressing cells (Fig. 5A). We conducted chromatin immunoprecipitation (ChIP) assays using anti-pSTAT1 antibody to examine if the interaction between the PSTAT1 complex and ISRE, which drives the expression of ISGs, is hampered by $\mathrm{N}$ protein. After IFN- $\alpha$ stimulation, pSTAT1 dimers were recruited to the ISRE of each examined ISG (IFIT2, MX2, OAS1, and PKR genes), while the occupancy of these regions with STAT1 complexes was reduced in the N 
A

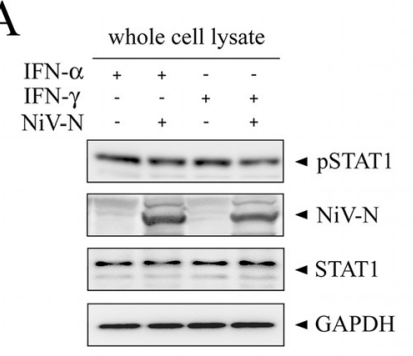

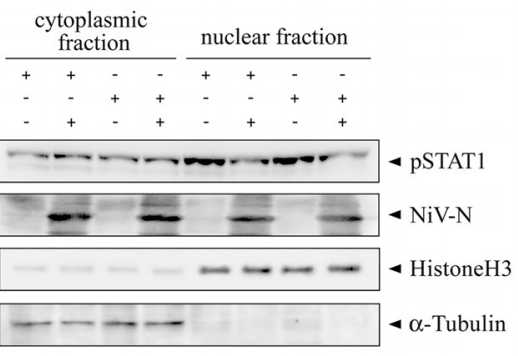

MX2-ISRE

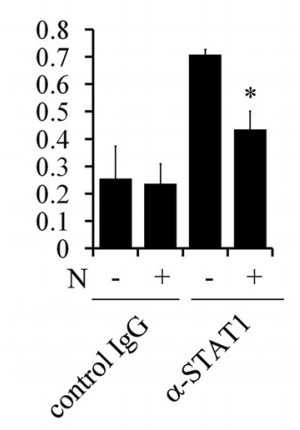

OAS1-ISRE

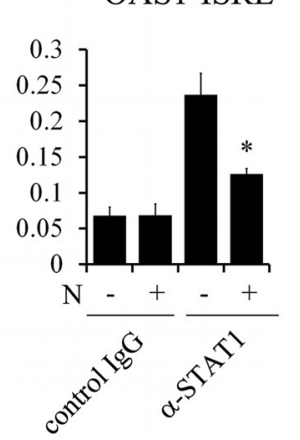

Relative nuclear pSTAT1

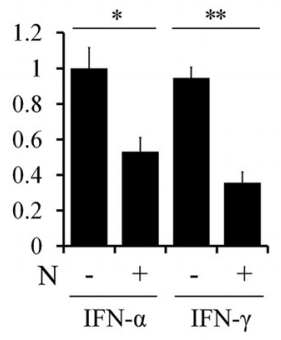

B

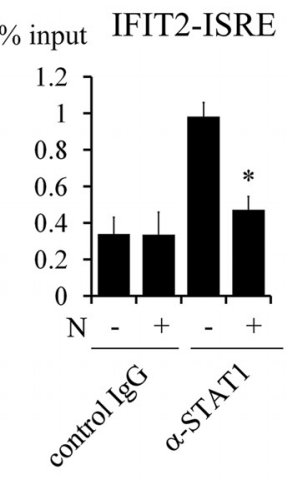

PKR-ISRE

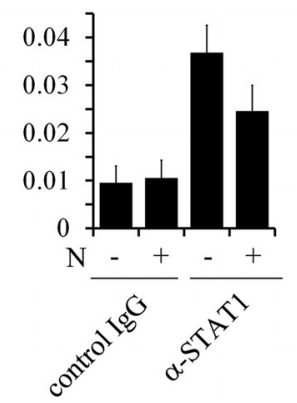

C
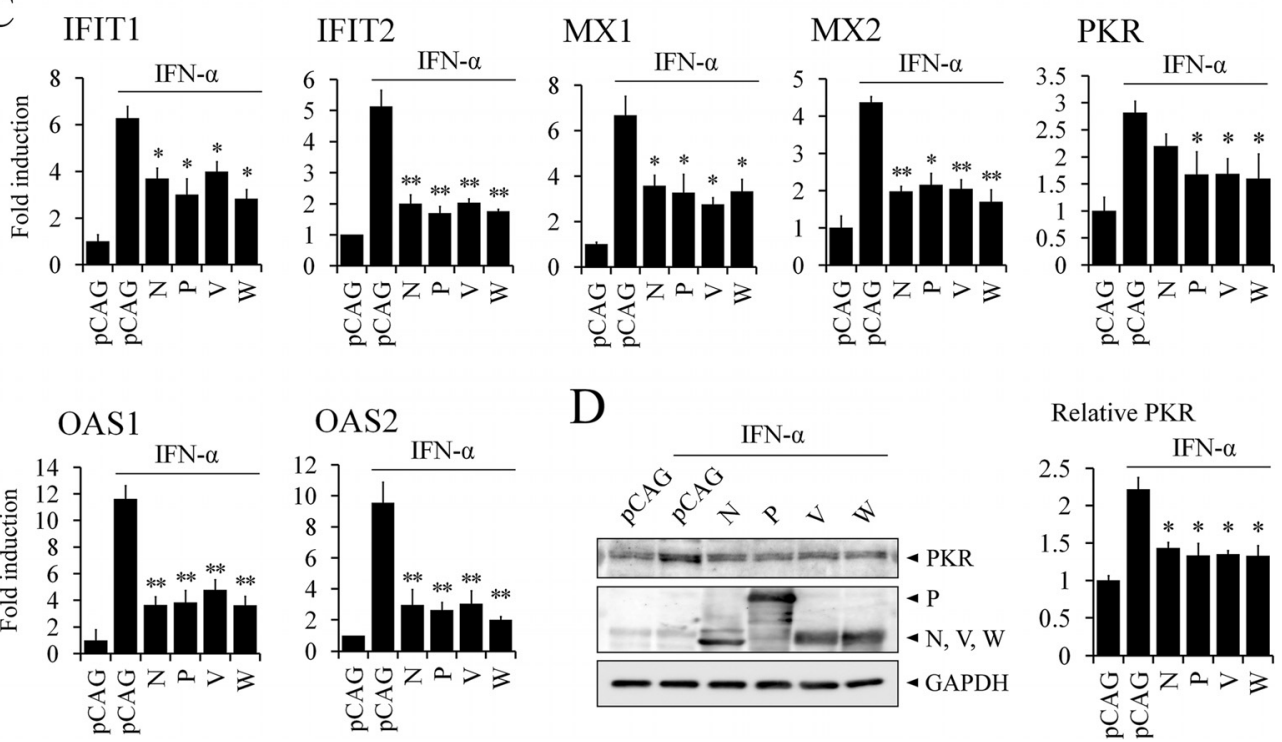

D
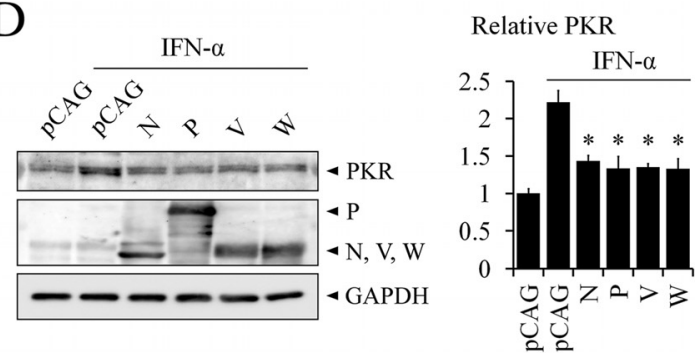

FIG 5 Influence of N protein on expression of ISGs. (A) 293T cells were treated with 1,000 U/ml IFN- $\alpha$ in the presence or absence of NiV-N protein. The component proteins were fractionated into nuclear and cytoplasmic fractions. The whole-cell lysate and fractionated samples were subjected to SDS-PAGE to examine if the NiV-N protein decreased the nuclear pSTAT1 level. The relative nuclear STAT1 level (pSTAT1/histone H3) was measured by densitometric analysis using ImageJ software, and mean values for three independent experiments are shown. Error bars indicate standard deviations. (B) 293T cells were transfected with a NiV-N expression plasmid or empty vector, and a chromatin immunoprecipitation assay was carried out with anti-STAT1 antibody (E-23) or control lgG (ab37415-5) after treatment with $1,000 \mathrm{U} / \mathrm{ml} \mathrm{IFN-} \alpha$. Enrichment of ISG promoters (IFIT2, MX2, OAS1, and PKR) was measured by quantitative PCR, and the amount of precipitated DNA relative to the amount of input DNA is shown as a percentage of the input. The experiment was repeated three times independently, and error bars show standard deviations. ${ }^{*}, P<0.05$. (C) Expression of mRNAs of ISGs $8 \mathrm{~h}$ (IFIT2, OAS2, and PKR), $16 \mathrm{~h}$ (MX2 and OAS1), and $24 \mathrm{~h}$ (IFIT1 and MX1) after IFN- $\alpha$ treatment of 293 T cells, with or without NiV-N expression, was measured by quantitative RT-PCR. GAPDH mRNA was detected as an internal control. Values shown are representative of three independent experiments. Error bars indicate standard deviations. *,$P<0.05 ;{ }^{* *}, P<0.01$. (D) Expression plasmids for antagonists (pCAGGS-N and -P and pCMV-myc-V and $-\mathrm{W}$ ) were transfected into 293T cells, and the protein expression level of PKR $16 \mathrm{~h}$ after IFN- $\alpha$ treatment was analyzed by Western blotting. PKR was detected by use of an anti-PKR antibody. Densitometric analysis of the protein bands was conducted by use of ImageJ software, and the relative PKR level (PKR/GAPDH) was calculated. Mean values for two independent experiments are shown. Error bars indicate standard deviations. 
protein-expressing cells (Fig. 5B). We also examined the influence of $\mathrm{N}$ protein on the induction of ISGs by measuring the mRNA levels of representative ISGs in the presence or absence of $\mathrm{N}$ protein. In agreement with the ChIP assay results, the mRNA levels of six of the seven tested ISGs (IFIT1, IFIT2, MX1, MX2, OAS1, and OAS2) were significantly downregulated in the $\mathrm{N}$ protein-expressing cells as assessed by quantitative reverse transcription-PCR (qRT-PCR). The expression of the PKR gene also tended to be suppressed by the $\mathrm{N}$ protein, although the difference in expression level did not reach statistical significance. Induction of mRNA by IFN- $\alpha$ stimulation was relatively weak for the examined ISGs, and this seemed to depend on a combination of the cell type used and the subtype of IFN- $\alpha$. Notably, N protein inhibited the expression of the IFIT1, IFIT2, $M X 1, M X 2, O A S 1$, and OAS2 genes as strongly as the P gene products did. Although the PKR inhibition by the $N$ protein was slightly weaker than that by the $P, V$, and $W$ proteins at the mRNA level (Fig. 5C), we detected that the $\mathrm{N}$ protein significantly suppressed PKR induction at the protein level, similar to the suppression induced by the $\mathrm{P}$ gene products (Fig. 5D). Taken together, the data showed that the NiV-N protein hampered STAT1 complex formation, which caused a reduction in both the amount of active pSTAT1 complexes in the nucleus and the induction of ISGs.

\section{DISCUSSION}

In paramyxoviruses, the $\mathrm{P}$ gene products block host IFN responses at various steps of the JAK/STAT signaling pathway. The $\mathrm{P}, \mathrm{V}$, and $\mathrm{W}$ proteins of NiV are all able to interact with STAT1 by its common $\mathrm{N}$-terminal region to prevent host IFN responses (31). The V protein suppresses IFN responses by interfering with the nuclear translocation of STAT1, and the $\mathrm{W}$ protein holds the inactive form of STAT1 in the nucleus and prevents its activation $(31,54)$. The $V$ protein also associates with STAT2 and prevents the nuclear accumulation of STAT2 (55). Additionally, the $C$ protein has been reported to prevent IFN signaling (56). These various routes for suppressing IFN responses suggest that multiple mechanisms to inhibit the IFN pathway are required for effective viral replication. In the present study, we demonstrated that the henipavirus $\mathrm{N}$ protein also acts to suppress IFN responses by hampering the JAK/STAT pathway. We found that, similarly to the $\mathrm{P}$ gene products, the $\mathrm{N}$ protein interfered with the nucleocytoplasmic transport of STATs; however, the N protein did not associate with STATs or the transport system components $\operatorname{Imp} \alpha 5, \operatorname{Imp} \beta 1$, and Ran. Also distinct from the mechanisms employed by $\mathrm{P}, \mathrm{V}$, and $\mathrm{W}$, the $\mathrm{N}$ protein did not inhibit phosphorylation of STAT. The mechanism responsible for IFN antagonism by the $\mathrm{N}$ protein seems to be different from any other reported methods.

The picornaviruses, such as poliovirus and rhinovirus, are known to suppress the nuclear transport of STATs through the degradation of the Nup153 and p62 proteins, which are components of the nuclear pore complex on the nuclear membrane (57). This suppression results in the indiscriminant prevention of host protein translocation to the nucleus. In contrast, NiV-N failed to prevent the nuclear transfer of Kir/Gem-W269E, which is a known cargo of Imp $\alpha 5$ (50). This result demonstrates that the IFN response suppression by henipavirus $\mathrm{N}$ proteins is not due to an indiscriminant interruption of host protein nuclear transport but instead is the result of specifically affecting STATs. Therefore, the $\mathrm{N}$ protein does not affect the nuclear pore complex to prevent STAT nuclear transfer. Meanwhile, in both LMB-treated and untreated cells, the nuclear accumulation of STAT2 after IFN- $\alpha$ stimulation was interrupted by the expression of $\mathrm{N}$ protein, demonstrating that the $\mathrm{N}$ protein did not enhance the CRM1 nuclear export system but instead inhibited the import of STATs.

In the presence of $\mathrm{N}$ protein, activated STATs failed to efficiently accumulate in the nucleus, which resulted in a downregulation of IFN responses. As shown by the BN-PAGE analysis, we detected a marked impairment of STAT complex formation in the N protein-expressing cells, even though the activation of STATs via phosphorylation was intact in these cells. Indeed, the downregulation of STAT complex formation caused a reduction in the nuclear PSTAT1 level and its association with ISRE, and this resulted in a suppression of ISG expression. Together, these findings 
suggest that the $\mathrm{N}$ protein prevents the translocation of activated STATs from the cytoplasm to the nucleus by preventing complex formation of STATs. Direct binding between $\mathrm{N}$ protein and STAT1, -2 , or -3 was, however, not detected. The N protein may bind to an unknown factor that is required for PSTAT complex formation.

In the reporter assay, the $\mathrm{N}$ protein significantly suppressed IFN- $\gamma$ responses as well as the $\mathrm{P}$ gene product did, while the inhibition of IFN- $\alpha$ responses by the $\mathrm{N}$ protein was weaker than that induced by the P protein. However, in the qRT-PCR assay, the N protein significantly suppressed the expression of some representative ISGs which are normally induced by IFN- $\alpha$ stimulation, similarly to the suppression induced by the $\mathrm{P}$, $\mathrm{V}$, and $\mathrm{W}$ proteins. These results suggest that the IFN antagonism of $\mathrm{N}$ protein is comparable to that of the P gene products for a subset of ISGs. The IFN- $\alpha$ responses found in the reporter assay and those observed in the RNA quantification of ISGs seemed to be differently suppressed by the $\mathrm{N}$ protein, but this discrepancy may have been caused by differences in the binding affinity of the STAT complex for ISREs. Because ISREs and their adjacent sequences are variable (58-61), the binding affinity of the STAT complex for them is likely not constant. The lower abundance of STAT complexes in the nucleus should strongly affect ISGs driven by ISREs that have lower affinities for binding the STAT complex. Thus, the $\mathrm{N}$ protein strongly suppressed transcription of some ISGs, and this seemed to have a nonnegligible effect on host IFN responses. Additionally, for paramyxoviruses, the $\mathrm{N}$ protein is the most abundant viral protein in infected cells (62-65); this fact increases the importance of the inhibitory effect of the $\mathrm{N}$ protein.

$\mathrm{N}$ proteins expressed alone in cultured cells are partially transported into the nucleus, whereas in the presence of $\mathrm{P}$ protein, the $\mathrm{N}$ proteins are predominantly retained in the cytoplasm because of the interaction between $\mathrm{N}$ and $\mathrm{P}$ proteins $(34,53)$. We investigated the influence of the interaction between NiV-N and NiV-P proteins on their IFN antagonist activities (Fig. 1B). The coexistence of $\mathrm{N}$ and $\mathrm{P}$ proteins caused no change in their antagonistic activities, suggesting that inhibition by $\mathrm{N}$ and $\mathrm{P}$ proteins each affects the IFN pathway independently and by different mechanisms. Indeed, in contrast to the P protein, NiV-N did not associate with STATs. Additionally, coexpression of the mutant $P$ protein ( $\mathrm{mP}$ ), which was devoid of most of its ability to inhibit the IFN- $\gamma$ response but was able to associate with the $\mathrm{N}$ protein, did not abrogate the IFN suppression by the $\mathrm{N}$ protein. This also indicates that N-P interaction does not impair the antagonistic activity and suggests that the IFN inhibition induced by the $\mathrm{N}$ protein occurred in the cytoplasm. This is consistent with the finding that IFN inhibition by the $\mathrm{N}$ protein was due to the suppression of STAT complex formation.

We previously reported the IFN antagonist activity of a morbillivirus N protein (32). We found many common features in the mechanism of IFN response suppression between the morbilliviruses and henipaviruses. Here we demonstrated that the $N$ proteins of the henipaviruses show antagonistic activity against IFN responses via hampering the nuclear accumulation of activated STAT complexes similarly to the morbillivirus $\mathrm{N}$ protein mechanism. NiV-N neither prevented the phosphorylation of STATs nor inhibited the $\operatorname{Imp} \alpha 5$ nuclear import system. These results are also consistent with those for morbilliviruses (32). However, notably different features between henipavirus and morbillivirus $\mathrm{N}$ proteins were also demonstrated in this study. Previously, we reported that MV-N requires its own nuclear translocation to prevent the nuclear accumulation of STAT complexes and that coexpression of MV-P with MV-N abolished the inhibitory activity of the N protein (32). Unlike that of MV-N, the antagonistic activity of NiV-N was not prevented by the presence of NiV-P protein, and NiV-N was observed to have intact activity in the cytoplasm. Furthermore, this mechanism of inhibition of IFN responses by NiV-N was due to the inhibition of complex formation by activated STATs, which is different from the mechanism of MV-N (32). It will be important to consider the influence of this novel IFN antagonist activity of $\mathrm{N}$ protein on the pathogenicity of henipaviruses. 


\section{MATERIALS AND METHODS}

Cells and antibodies. HEK-293 (human embryonic kidney cells), 293T (HEK-293 cells stably expressing the simian virus 40 [SV40] large T antigen), HeLa (human epithelial carcinoma cells), and Cos7 (SV40-transformed African green monkey kidney fibroblasts) cells (66) were maintained in Dulbecco's modified Eagle's medium (DMEM) (Sigma-Aldrich) supplemented with $5 \%$ fetal bovine serum (JRH Bioscience), $2 \mathrm{mM}$ L-glutamine, $100 \mathrm{U} / \mathrm{ml}$ penicillin, and $0.1 \mathrm{mg} / \mathrm{ml}$ streptomycin at $37^{\circ} \mathrm{C}$ in $5 \% \mathrm{CO}_{2}$. Polyclonal antibodies against NiV-N, NiV-P, and MV-N were prepared as previously described $(49,67)$. The following antibodies were purchased: rabbit antibodies against STAT1 p84/p91 (E-23 [sc-346]; Santa Cruz), phospho-STAT1 (Tyr701) (9171; Cell Signaling Technology), STAT2 (C-20 [sc-476]; Santa Cruz), p-Stat2 (Tyr690) (sc-21689-R; Santa Cruz), STAT3 (H-190 [sc-7179]; Santa Cruz), histone H3 (D1H2) (4499P; Cell Signaling Technology), tubulin (H300 [sc-5546]; Santa Cruz), PKR (D-20 [sc-708]; Santa Cruz), HA tag (631207; Clontech), and c-Myc tag (C3956; Sigma-Aldrich); a rabbit IgG isotype control antibody (ab37415-5; Abcam); and mouse antibodies against STAT1 $\alpha$ p91 (C-111 [sc-417]; Santa Cruz), STAT2 (A-7 [sc-1668] and A-9 [sc-166201]; Santa Cruz), glyceraldehyde-3-phosphate dehydrogenase (GAPDH) (MAB374; Millipore), HA tag (H9654; Sigma-Aldrich), and c-Myc (631206; Clontech). The following secondary antibodies for indirect immunofluorescence assays were purchased from Invitrogen: Alexa Fluor 488-conjugated antibodies against mouse or rabbit lgG and Alexa Fluor 568-conjugated antibodies against mouse or rabbit IgG. Polyclonal anti-rabbit and anti-mouse immunoglobulins conjugated to horseradish peroxidase (HRP) were obtained from Dako Cytomation.

Plasmids. Genes for wild-type N protein (wt-N), N core domain, N tail domain, C-terminally HAtagged $N$ protein, and wild-type $P$ protein (wt-P) from the NiV Malaysia strain (accession no. AF212302.2) were cloned into pCAGGS mammalian expression vectors (72). The NiV N, P, V, and W genes were also cloned into pCMV-Myc and -HA vectors (Clontech). The HeV-N gene (accession no. NC_001906) was generated by mutagenesis from the NiV-N gene and was cloned into pCAGGS and pCMV-Myc vectors. The plasmids for MV-N and NiV-N-S541A were constructed as previously described (49). The generation of the point mutants and deletion mutants used in this study was conducted as previously described (34, 67-70). The $P$ protein mutant $\mathrm{G} 125 \mathrm{E}$ ( $\mathrm{mP}$ ) cannot express the $\mathrm{C}$ protein due to a mutation, as previously described (71). The $\operatorname{Imp} \alpha 5, \operatorname{Imp} \beta 1$, and Ran genes were obtained from cDNAs that were reverse transcribed from the total RNA of HEK-293 cells and were cloned into a pCMV-HA vector. Kir/Gem-W269G was cloned into a pEGFP-C1 vector (GenBank accession no. U55763). The phRL-TK (Int-) and pISRE-Luc vectors were purchased from Promega and Clontech, respectively. The pGAS-Luc vector, which expresses firefly luciferase (Fluc), was constructed as previously described (32).

Luciferase reporter assay. 293T cells in 24-well plates were transfected with $0.2 \mu \mathrm{g}$ of pISRE-Luc or $0.004 \mu \mathrm{g}$ of pGAS-Luc, $0.001 \mu \mathrm{g}$ of phRL-TK (Int-) vector, and $0.6 \mu \mathrm{g}$ of empty vector or a plasmid for an antagonistic protein by use of Lipofectamine 2000 transfection reagent (Life Technologies). The phRL-TK (Int-) vector, which expresses renilla luciferase (Rluc), was used as a control for transfection efficiency. At $24 \mathrm{~h}$ posttransfection, the medium was replaced with fresh medium containing 1,000 $\mathrm{U} / \mathrm{ml}$ of universal type I IFN- $\alpha$ (PBL Interferon Source) or $1,000 \mathrm{U} / \mathrm{ml}$ of recombinant human IFN- $\gamma$ (SigmaAldrich) and incubated at $37^{\circ} \mathrm{C}$ for $24 \mathrm{~h}$. The cells were harvested and lysed in passive lysis buffer (Promega) for $30 \mathrm{~min}$ at $4^{\circ} \mathrm{C}$, and the cell debris was removed from the lysate by centrifugation. The activity of the reporter gene was evaluated using a dual-luciferase reporter assay system (Promega) according to the manufacturer's instructions. The Fluc/Rluc value was calculated from at least three independent experiments containing triplicate samples. To verify protein expression, each cell lysate was subjected to Western blot analysis.

Western blot analysis. 293T cells were transfected with expression plasmids by use of FuGENE 6 transfection reagent (Roche Applied Science). Cell fractionation was performed with a LysoPure nuclear and cytoplasmic extraction kit (Wako) according to the manufacturer's protocol. At $24 \mathrm{~h}$ posttransfection, the cells were washed in phosphate-buffered saline (PBS) and lysed in lysis buffer (5 mM EDTA and 0.5\% Triton X-100 in PBS) supplemented with a protease inhibitor cocktail (BD Bioscience) and PhosSTOP phosphatase inhibitor cocktail (Roche Applied Science). The lysates were separated by 8 to $15 \%$ SDS-PAGE and transferred to an Immobilon-P transfer membrane (Millipore). The membrane was blocked with a 4-fold dilution of Block-ACE (DS Pharma Biomedical) and subsequently incubated with an appropriate dilution of a primary antibody for $2 \mathrm{~h}$ at $37^{\circ} \mathrm{C}$ or overnight at $4^{\circ} \mathrm{C}$. The membrane was washed five times with $0.05 \%$ PBST ( $1 \times$ PBS with $0.05 \%$ Tween 20 ), followed by incubation with a 1:2,000 dilution of polyclonal anti-rabbit or anti-mouse immunoglobulins conjugated to HRP for $1 \mathrm{~h}$ at $37^{\circ} \mathrm{C}$. The immunoreactive bands were detected using ECL Prime Western blotting detection reagents (GE Healthcare). Chemiluminescence was visualized and scanned by use of a luminescence image analyzer (LAS-1000UV minisystem; Fujifilm). Each experiment was repeated independently at least twice.

Indirect immunofluorescence assay. Cos7 or HeLa cells in 24-well plates were transfected with 0.6 $\mu \mathrm{g}$ of expression vectors for appropriate proteins by use of FuGENE 6 transfection reagent according to the manufacturer's instructions. Treatment with $20 \mathrm{nM}$ leptomycin B (LMB; Sigma-Aldrich) was performed at $37^{\circ} \mathrm{C}$ for 1 or $16 \mathrm{~h}$. At $24 \mathrm{~h}$ posttransfection, the cells were treated with $2,000 \mathrm{U} / \mathrm{ml}$ of universal type I IFN or $1,000 \mathrm{U} / \mathrm{ml}$ of recombinant human IFN- $\gamma$ and were incubated at $37^{\circ} \mathrm{C}$ for $30 \mathrm{~min}$. The cells were fixed with 3\% paraformaldehyde in PBS for 30 min and permeabilized with $0.2 \%$ Triton X-100 in PBS for $5 \mathrm{~min}$. The cells were incubated with a primary antibody, followed by incubation with a 1:1,000 dilution of Alexa Fluor 488 or 568-conjugated $\mathrm{F}\left(\mathrm{abb}^{\prime}\right)_{2}$ fragment supplemented with Hoechst 33342 (Cambrex Bio Science). A confocal laser scanning microscope (Fluoview FV1000-D system; Olympus) was used to detect the fluorescence and to generate z-stack images. The experiments were repeated three times independently.

BN-PAGE. BN-PAGE is a method that separates protein complexes by using Coomassie brilliant blue (CBB) G-250 under native conditions. The CBB G-250 associates with protein complexes and mildly masks 
their net charge. 293T cells in six-well plates were transfected with $3.0 \mu \mathrm{g}$ of pCAGGS-NiV-N or empty vector by use of FuGENE 6 transfection reagent. At $24 \mathrm{~h}$ posttransfection, the cells were treated with $1,000 \mathrm{U} / \mathrm{ml}$ of universal type I IFN- $\alpha$ or recombinant human IFN- $\gamma$, incubated at $37^{\circ} \mathrm{C}$ for $20 \mathrm{~min}$, and fixed with $20 \mathrm{mM}$ dimethyl suberimidate for $30 \mathrm{~min}$. The cells were lysed in lysis buffer ( $2.5 \mathrm{mM}$ EDTA and $0.25 \%$ Triton X-100 in PBS) supplemented with protease inhibitor cocktail and PhosSTOP phosphatase inhibitor cocktail at $4^{\circ} \mathrm{C}$ for $15 \mathrm{~min}$. The lysates were then diluted with $10 \times$ sample buffer $(5 \%$ [wt/vol] CBB G-250, $500 \mathrm{mM}$ 6-aminocaproic acid, and $100 \mathrm{mM}$ bis-Tris [pH 7.0]). The component proteins were separated in a $6.5 \%$ native polyacrylamide gel (with $50 \mathrm{mM}$ bis-Tris [pH 7.0] and $500 \mathrm{mM}$ 6-aminocaproic acid) in native running buffer (anode, $50 \mathrm{mM}$ bis-Tris [pH 7.0]; and cathode, 0.02\% CBB G-250, $50 \mathrm{mM}$ Tricine, and $15 \mathrm{mM}$ bis-Tris [pH 7.0]) and then transferred onto an Immobilon-P transfer membrane after treatment with denaturation buffer (2\% SDS and $50 \mathrm{mM}$ Tris- $\mathrm{HCl}[\mathrm{pH} 7.0]$ ) at $50^{\circ} \mathrm{C}$ for $15 \mathrm{~min}$. Bands of the protein complexes containing PSTAT1 from the membrane were detected with an anti-phosphoSTAT1 (Tyr701) antibody as described above. The experiment was conducted three times independently.

Immunoprecipitation. 293T cells in 12-well plates were transfected with $1.2 \mu \mathrm{g}$ of expression plasmids by use of FuGENE 6 transfection reagent. At $24 \mathrm{~h}$ posttransfection, the cells were lysed. Protein A Sepharose CL-4B (Amersham Biosciences) or protein G Sepharose 4 Fast Flow (GE Healthcare) was preincubated with the appropriate antibody for $2 \mathrm{~h}$ at $4^{\circ} \mathrm{C}$. The beads were washed five times with PBS and incubated with the cell lysate for $4 \mathrm{~h}$ at $4^{\circ} \mathrm{C}$. After being washed five times with PBS, the beads were suspended in $2 \times$ Laemmli SDS sample buffer. The proteins were analyzed by Western blotting as described above. Each experiment was independently repeated at least twice.

ChIP assay. 293T cells in six-well plates were transfected with $3.0 \mu \mathrm{g}$ of pCAGGS-NiV-N or empty vector. At $24 \mathrm{~h}$ posttransfection, the cells were treated with $1,000 \mathrm{U} / \mathrm{ml}$ of IFN- $\alpha$ for $30 \mathrm{~min}$ and were fixed with $1 \%$ formaldehyde for $7 \mathrm{~min}$. The cross-linking was stopped by addition of $125 \mathrm{mM}$ glycine. The fixed chromatin samples were sonicated (Tomy DU-201 sonicator; $10 \mathrm{~s}, 8$ times) and were sheared into fragments of approximately 500 bp in SDS lysis buffer (1\% SDS, $10 \mathrm{mM}$ EDTA [pH 8.0], and $50 \mathrm{mM}$ Tris-HCl [pH 8.0] with protease inhibitor cocktail and PhosSTOP phosphatase inhibitor cocktail). The solution was diluted 10 -fold with dilution buffer $(1.1 \%$ Triton X-100, $0.11 \%$ sodium deoxycholate [DOC], $50 \mathrm{mM}$ Tris-HCl [pH 8.0], and $167 \mathrm{mM} \mathrm{NaCl}$ with protease inhibitors and phosphatase inhibitors). A 1/10 volume of the solution was used as input, and a 1/3 volume of the solution was precleared with protein $\mathrm{G} / \mathrm{salmon}$ sperm DNA at $4^{\circ} \mathrm{C}$ for $4 \mathrm{~h}$ before being incubated with $6 \mu \mathrm{g}$ of anti-STAT1 antibody (E23; Santa Cruz) or control rabbit IgG (Abcam) at $4^{\circ} \mathrm{C}$. After $20 \mathrm{~h}$ of incubation, $25 \mu \mathrm{l}$ of protein $\mathrm{G} /$ salmon sperm DNA was added to the solution, and the samples were incubated at $4^{\circ} \mathrm{C}$ for $2 \mathrm{~h}$. The beads were washed with RIPA buffer (1\% Triton X-100, 0.1\% SDS, 0.1\% DOC, 1 mM EDTA [pH 8.0], and $50 \mathrm{mM}$ Tris-HCl [pH 8.0]) with $150 \mathrm{mM} \mathrm{NaCl}$, RIPA buffer with $500 \mathrm{mM} \mathrm{NaCl}$, LiCl wash solution (0.5\% DOC, 0.5\% NP-40, 1 mM EDTA [pH 8.0], $250 \mathrm{mM} \mathrm{LiCl}$, and $10 \mathrm{mM}$ Tris-HCl [pH 8.0]), and Tris-EDTA (TE). The beads were resuspended in 200 $\mu \mathrm{l}$ of direct elution buffer (0.5\% SDS, $5 \mathrm{mM}$ EDTA [pH 8.0], $300 \mathrm{mM} \mathrm{NaCl}$, and $10 \mathrm{mM}$ Tris-HCl [pH 8.0]) and were incubated with input solution at $65^{\circ} \mathrm{C}$ for $4 \mathrm{~h}$ to reverse the formaldehyde cross-linking. The samples were treated with $4 \mu \mathrm{g}$ of RNase A for $30 \mathrm{~min}$ and then with $10 \mu \mathrm{g}$ of proteinase $\mathrm{K}$ for $1 \mathrm{~h}$. DNA fragments were extracted with phenol-chloroform and were purified by ethanol precipitation.

Quantitative RT-PCR. Total RNA was extracted from 293T cells by use of Isogen (Nippon Gene), and reverse transcription was conducted with an oligo(dT) primer with PrimeScript reverse transcriptase (TaKaRa). Real-time-PCR was conducted with IFIT1-specific (5'-TAGCCAGATCTCAGAGGAGCC-3' and 5'CCATTTGTACTCATGGTTGCTG-3'), IFIT2-specific (5'-TGAAAGAGCGAAGGTGTGCT-3' and 5'-AGAGGGTCAAT GGCGTTCTG-3'), MX1-specific (5'-ATCCAGCCACCATTCCAAGG-3' and 5'-TGCGATGTCCACTTCGGAAA-3'), MX2-specific (5'-TGAACGTGCAGCGAGCTT-3' and 5'-GGCTTGTGGGCCTTAGACAT-3'), OAS1-specific (5'-GGTG GAGTTCGATGTGCTG-3' and 5'-AGGTTTATAGCCGCCAGTCA-3'), OAS2-specific (5'-CCAGCTGAGAGCAATGGG AA-3' and 5'-TGGTGTTCACCATCTCGTCG-3'), PKR-specific (5'-GGCTGTTGGGATGGATTTGA-3' and $5^{\prime}$-TGG ATGAAAAGGCACTTAGTC- $3^{\prime}$ ), and ADAR1-specific (5'-AGCAAGAAGCAAGGCAAGCA-3' and $5^{\prime}$-TGCTTCTG GGGACCTTGAGA-3') primers and with SYBR Ex Taq premix (TaKaRa). GAPDH was detected as an internal control (with primers 5'-AACATCATCCCTGCCTCTACTG-3' and 5'-GCTTCACCACCTTCTTGATGTC-3'). Primers for ChIP assays were designed within $1 \mathrm{~kb}$ of transcription start sites or estimated ISREs for IFIT2 (5'-GCCGATGAAACATCCCTCT- $3^{\prime}$ and $5^{\prime}$-TTाTTCCTCCGGAGCTGAG-3'), MX2 (5'-CTTGGTGAATGTGGCTTG TG-3' and 5'-TTTCTGCTCCTCACACCAGA-3'), OAS1 (5'-TGTTGGCTGGAGGTTAAAATG-3' and 5'-TTGTCCT TTAGCCAGCAACA-3'), and PKR (5'-CCGTGAAGAATTITATCAGTGC-3' and 5'-GCCACTAGGCCTATTCGTC $\left.\Pi-3^{\prime}\right)$. All real-time PCR assays were conducted on a Rotor-Gene Q cycler (Qiagen). Data are from two independent experiments performed in triplicate.

\section{ACKNOWLEDGMENT}

This study was supported by a grant-in-aid from the Ministry of Education, Culture, Sports, Science, and Technology, Japan.

\section{REFERENCES}

1. Chua KB, Bellini WJ, Rota PA, Harcourt BH, Tamin A, Lam SK, Ksiazek TG, Rollin PE, Zaki SR, Shieh W, Goldsmith CS, Gubler DJ, Roehrig JT, Eaton B, Gould AR, Olson J, Field H, Daniels P, Ling AE, Peters CJ, Anderson LJ, Mahy BW. 2000. Nipah virus: a recently emergent deadly paramyxovirus. Science 288:1432-1435. https://doi.org/10.1126/science .288 .5470 .1432 .
2. Ksiazek TG, Rota PA, Rollin PE. 2011. A review of Nipah and Hendra viruses with an historical aside. Virus Res 162:173-183. https://doi.org/ 10.1016/j.virusres.2011.09.026.

3. Halpin K, Mungall BA. 2007. Recent progress in henipavirus research. Comp Immunol Microbiol Infect Dis 30:287-307. https://doi.org/10 .1016/j.cimid.2007.05.008 
4. Chua KB. 2003. Nipah virus outbreak in Malaysia. J Clin Virol 26:265-275. https://doi.org/10.1016/S1386-6532(02)00268-8.

5. Harcourt BH, Tamin A, Ksiazek TG, Rollin PE, Anderson LJ, Bellini WJ, Rota PA. 2000. Molecular characterization of Nipah virus, a newly emergent paramyxovirus. Virology 271:334-349. https://doi.org/10.1006/viro.2000 .0340 .

6. Mohd Nor MN, Gan CH, Ong BL. 2000. Nipah virus infection of pigs in peninsular Malaysia. Rev Sci Tech 19:160-165. https://doi.org/10.20506/ rst.19.1.1202.

7. Goh KJ, Tan CT, Chew NK, Tan PS, Kamarulzaman A, Sarji SA, Wong KT, Abdullah BJ, Chua KB, Lam SK. 2000. Clinical features of Nipah virus encephalitis among pig farmers in Malaysia. $\mathrm{N}$ Engl J Med 342: 1229-1235. https://doi.org/10.1056/NEJM200004273421701.

8. Homaira N, Rahman M, Hossain MJ, Epstein JH, Sultana R, Khan MS, Podder G, Nahar K, Ahmed B, Gurley ES, Daszak P, Lipkin WI, Rollin PE, Comer JA, Ksiazek TG, Luby SP. 2010. Nipah virus outbreak with personto-person transmission in a district of Bangladesh, 2007. Epidemiol Infect 138:1630-1636. https://doi.org/10.1017/S0950268810000695.

9. Luby SP, Gurley ES, Hossain MJ. 2009. Transmission of human infection with Nipah virus. Clin Infect Dis 49:1743-1748. https://doi.org/10.1086/ 647951.

10. Luby SP, Hossain MJ, Gurley ES, Ahmed BN, Banu S, Khan SU, Homaira N, Rota PA, Rollin PE, Comer JA, Kenah E, Ksiazek TG, Rahman M. 2009. Recurrent zoonotic transmission of Nipah virus into humans, Bangladesh, 2001-2007. Emerg Infect Dis 15:1229-1235. https://doi.org/10 .3201/eid1508.081237.

11. Chadha MS, Comer JA, Lowe L, Rota PA, Rollin PE, Bellini WJ, Ksiazek TG, Mishra A. 2006. Nipah virus-associated encephalitis outbreak, Siliguri, India. Emerg Infect Dis 12:235-240. https://doi.org/10.3201/eid1202 .051247.

12. Hsu VP, Hossain MJ, Parashar UD, Ali MM, Ksiazek TG, Kuzmin I, Niezgoda M, Rupprecht C, Bresee J, Breiman RF. 2004. Nipah virus encephalitis reemergence, Bangladesh. Emerg Infect Dis 10:2082-2087. https://doi .org/10.3201/eid1012.040701.

13. Wang L, Harcourt BH, Yu M, Tamin A, Rota PA, Bellini WJ, Eaton BT. 2001. Molecular biology of Hendra and Nipah viruses. Microbes Infect 3:279-287. https://doi.org/10.1016/S1286-4579(01)01381-8.

14. Field H, Kung N. 2011. Henipaviruses - unanswered questions of lethal zoonoses. Curr Opin Virol 1:658-661. https://doi.org/10.1016/j.coviro .2011.10.025.

15. Playford EG, McCall B, Smith G, Slinko V, Allen G, Smith I, Moore F, Taylor C, Kung YH, Field H. 2010. Human Hendra virus encephalitis associated with equine outbreak, Australia, 2008. Emerg Infect Dis 16:219-223. https://doi.org/10.3201/eid1602.090552.

16. Lo MK, Rota PA. 2008. The emergence of Nipah virus, a highly pathogenic paramyxovirus. J Clin Virol 43:396-400. https://doi.org/10.1016/j .jcv.2008.08.007.

17. Kulkarni S, Volchkova V, Basler CF, Palese P, Volchkov VE, Shaw ML. 2009. Nipah virus edits its $\mathrm{P}$ gene at high frequency to express the $\mathrm{V}$ and $\mathrm{W}$ proteins. J Virol 83:3982-3987. https://doi.org/10.1128/JVI.02599-08.

18. Improta T, Schindler C, Horvath CM, Kerr IM, Stark GR, Darnell JE, Jr. 1994. Transcription factor ISGF-3 formation requires phosphorylated Stat91 protein, but Stat113 protein is phosphorylated independently of Stat91 protein. Proc Natl Acad Sci U S A 91:4776-4780. https://doi.org/10.1073/ pnas.91.11.4776.

19. Shuai K, Stark GR, Kerr IM, Darnell JE, Jr. 1993. A single phosphotyrosine residue of Stat91 required for gene activation by interferon-gamma. Science 261:1744-1746. https://doi.org/10.1126/science.7690989.

20. Schindler C, Shuai K, Prezioso VR, Darnell JE, Jr. 1992. Interferondependent tyrosine phosphorylation of a latent cytoplasmic transcription factor. Science 257:809-813. https://doi.org/10.1126/science .1496401 .

21. Mowen K, David M. 1998. Role of the STAT1-SH2 domain and STAT2 in the activation and nuclear translocation of STAT1. J Biol Chem 273: 30073-30076. https://doi.org/10.1074/jbc.273.46.30073.

22. $\mathrm{Fu} X Y$. 1992. A transcription factor with $\mathrm{SH}_{2}$ and $\mathrm{SH} 3$ domains is directly activated by an interferon alpha-induced cytoplasmic protein tyrosine kinase(s). Cell 70:323-335. https://doi.org/10.1016/0092-8674 (92)90106-M.

23. Horvath CM, Darnell JE, Jr. 1996. The antiviral state induced by alpha interferon and gamma interferon requires transcriptionally active Stat1 protein. J Virol 70:647-650.

24. Qureshi SA, Salditt-Georgieff M, Darnell JE, Jr. 1995. Tyrosinephosphorylated Stat1 and Stat2 plus a 48-kDa protein all contact DNA in forming interferon-stimulated-gene factor 3. Proc Natl Acad Sci U S A 92:3829-3833. https://doi.org/10.1073/pnas.92.9.3829.

25. Banninger G, Reich NC. 2004. STAT2 nuclear trafficking. J Biol Chem 279:39199-39206. https://doi.org/10.1074/jbc.M400815200.

26. Quimby BB, Dasso M. 2003. The small GTPase Ran: interpreting the signs. Curr Opin Cell Biol 15:338-344. https://doi.org/10.1016/S0955-0674 (03)00046-2.

27. Reich NC, Liu L. 2006. Tracking STAT nuclear traffic. Nat Rev Immunol 6:602-612. https://doi.org/10.1038/nri1885.

28. Nardozzi JD, Lott K, Cingolani G. 2010. Phosphorylation meets nuclear import: a review. Cell Commun Signal 8:32. https://doi.org/10.1186/1478 $-811 X-8-32$

29. Ciancanelli MJ, Volchkova VA, Shaw ML, Volchkov VE, Basler CF. 2009. Nipah virus sequesters inactive STAT1 in the nucleus via a P geneencoded mechanism. J Virol 83:7828-7841. https://doi.org/10.1128/JVI .02610-08.

30. Shaw ML. 2009. Henipaviruses employ a multifaceted approach to evade the antiviral interferon response. Viruses 1:1190-1203. https://doi.org/ 10.3390/v1031190.

31. Shaw ML, García-Sastre A, Palese P, Basler CF. 2004. Nipah virus V and W proteins have a common STAT1-binding domain yet inhibit STAT1 activation from the cytoplasmic and nuclear compartments, respectively. J Virol 78:5633-5641. https://doi.org/10.1128/JVI.78.11.5633-5641 .2004 .

32. Takayama I, Sato H, Watanabe A, Omi-Furutani M, Sugai A, Kanki K, Yoneda M, Kai C. 2012. The nucleocapsid protein of measles virus blocks host interferon response. Virology 424:45-55. https://doi.org/10.1016/j .virol.2011.12.011.

33. Sato H, Masuda M, Miura R, Yoneda M, Kai C. 2006. Morbillivirus nucleoprotein possesses a novel nuclear localization signal and a CRM1independent nuclear export signal. Virology 352:121-130. https://doi .org/10.1016/j.virol.2006.04.013.

34. Omi-Furutani M, Yoneda M, Fujita K, Ikeda F, Kai C. 2010. Novel phosphoprotein-interacting region in Nipah virus nucleocapsid protein and its involvement in viral replication. J Virol 84:9793-9799. https://doi .org/10.1128/JVI.00339-10.

35. Sugai A, Sato H, Hagiwara K, Kozuka-Hata H, Oyama M, Yoneda M, Kai C. 2014. Newly identified minor phosphorylation site threonine-279 of measles virus nucleoprotein is a prerequisite for nucleocapsid formation. J Virol 88:1140-1149. https://doi.org/10.1128/JVI.01718-13.

36. Bernard C, Gely S, Bourhis JM, Morelli X, Longhi S, Darbon H. 2009. Interaction between the C-terminal domains of $\mathrm{N}$ and $\mathrm{P}$ proteins of measles virus investigated by NMR. FEBS Lett 583:1084-1089. https:// doi.org/10.1016/j.febslet.2009.03.004.

37. Bourhis JM, Receveur-Bréchot V, Oglesbee $M$, Zhang $X$, Buccellato $M$, Darbon H, Canard B, Finet S, Longhi S. 2005. The intrinsically disordered C-terminal domain of the measles virus nucleoprotein interacts with the C-terminal domain of the phosphoprotein via two distinct sites and remains predominantly unfolded. Protein Sci 14:1975-1992. https://doi .org/10.1110/ps.051411805.

38. Myers TM, Pieters A, Moyer SA. 1997. A highly conserved region of the Sendai virus nucleocapsid protein contributes to the NP-NP binding domain. Virology 229:322-335. https://doi.org/10.1006/viro.1996.8429.

39. Heggeness MH, Scheid A, Choppin PW. 1981. The relationship of conformational changes in the Sendai virus nucleocapsid to proteolytic cleavage of the NP polypeptide. Virology 114:555-562. https://doi.org/ 10.1016/0042-6822(81)90235-X.

40. Platanias LC. 2005. Mechanisms of type-I- and type-Il-interferonmediated signalling. Nat Rev Immunol 5:375-386. https://doi.org/10 $.1038 /$ nri1604.

41. Marg A, Shan $Y$, Meyer T, Meissner T, Brandenburg M, Vinkemeier U. 2004. Nucleocytoplasmic shuttling by nucleoporins Nup153 and Nup214 and CRM1-dependent nuclear export control the subcellular distribution of latent Stat1. J Cell Biol 165:823-833. https://doi.org/10.1083/jcb .200403057.

42. Fagerlund R, Mélen K, Kinnunen L, Julkunen I. 2002. Arginine/lysine-rich nuclear localization signals mediate interactions between dimeric STATs and importin alpha 5. J Biol Chem 277:30072-30078. https://doi.org/10 .1074/jbc.M202943200.

43. Pumroy RA, Cingolani G. 2015. Diversification of importin- $\alpha$ isoforms in cellular trafficking and disease states. Biochem J 466:13-28. https://doi .org/10.1042/BJ20141186.

44. Frieman M, Yount B, Heise M, Kopecky-Bromberg SA, Palese P, Baric RS. 2007. Severe acute respiratory syndrome coronavirus ORF6 antagonizes 
STAT1 function by sequestering nuclear import factors on the rough endoplasmic reticulum/Golgi membrane. J Virol 81:9812-9824. https:// doi.org/10.1128/JVI.01012-07.

45. Lott K, Cingolani G. 2011. The importin $\beta$ binding domain as a master regulator of nucleocytoplasmic transport. Biochim Biophys Acta 1813: 1578-1592. https://doi.org/10.1016/j.bbamcr.2010.10.012.

46. Bednenko J, Cingolani G, Gerace L. 2003. Importin beta contains a $\mathrm{COOH}$-terminal nucleoporin binding region important for nuclear transport. J Cell Biol 162:391-401. https://doi.org/10.1083/jcb.200303085.

47. Fradin C, Zbaida D, Elbaum M. 2005. Dissociation of nuclear import cargo complexes by the protein Ran: a fluorescence correlation spectroscopy study. C R Biol 328:1073-1082. https://doi.org/10.1016/j.crvi.2005.10.003.

48. Künzler M, Hurt E. 2001. Targeting of Ran: variation on a common theme? J Cell Sci 114:3233-3241.

49. Huang M, Sato H, Hagiwara K, Watanabe A, Sugai A, Ikeda F, KozukaHata H, Oyama M, Yoneda M, Kai C. 2011. Determination of a phosphorylation site in Nipah virus nucleoprotein and its involvement in virus transcription. J Gen Virol 92:2133-2141. https://doi.org/10.1099/vir.0 .032342-0.

50. Mahalakshmi RN, Nagashima K, Ng MY, Inagaki N, Hunziker W, Béguin P. 2007. Nuclear transport of Kir/Gem requires specific signals and importin alpha5 and is regulated by calmodulin and predicted serine phosphorylations. Traffic 8:1150-1163. https://doi.org/10.1111/j.1600-0854.2007 .00598.x.

51. Frahm T, Hauser H, Köster M. 2006. IFN-type-l-mediated signaling is regulated by modulation of STAT2 nuclear export. J Cell Sci 119: 1092-1104. https://doi.org/10.1242/jcs.02822.

52. Kudo N, Matsumori N, Taoka H, Fujiwara D, Schreiner EP, Wolff B, Yoshida M, Horinouchi S. 1999. Leptomycin B inactivates CRM1/exportin 1 by covalent modification at a cysteine residue in the central conserved region. Proc Natl Acad Sci U S A 96:9112-9117. https://doi.org/10.1073/ pnas.96.16.9112.

53. Huber M, Cattaneo R, Spielhofer P, Orvell C, Norrby E, Messerli M, Perriard JC, Billeter MA. 1991. Measles virus phosphoprotein retains the nucleocapsid protein in the cytoplasm. Virology 185:299-308. https:// doi.org/10.1016/0042-6822(91)90777-9.

54. Shaw ML, Cardenas WB, Zamarin D, Palese P, Basler CF. 2005. Nuclear localization of the Nipah virus $W$ protein allows for inhibition of both virus- and Toll-like receptor 3-triggered signaling pathways. J Virol 79:6078-6088. https://doi.org/10.1128/JVI.79.10.6078-6088.2005.

55. Rodriguez JJ, Parisien JP, Horvath CM. 2002. Nipah virus V protein evades alpha and gamma interferons by preventing STAT1 and STAT2 activation and nuclear accumulation. J Virol 76:11476-11483. https://doi.org/10 $.1128 / J V I .76 .22 .11476-11483.2002$.

56. Park MS, Shaw ML, Muñoz-Jordan J, Cros JF, Nakaya T, Bouvier N, Palese P, García-Sastre A, Basler CF. 2003. Newcastle disease virus (NDV)-based assay demonstrates interferon-antagonist activity for the NDV $V$ protein and the Nipah virus V, W, and C proteins. J Virol 77:1501-1511. https:// doi.org/10.1128/JVI.77.2.1501-1511.2003.

57. Gustin KE, Sarnow P. 2002. Inhibition of nuclear import and alteration of nuclear pore complex composition by rhinovirus. J Virol 76:8787-8796. https://doi.org/10.1128/JVl.76.17.8787-8796.2002.

58. Blaszczyk K, Olejnik A, Nowicka H, Ozgyin L, Chen YL, Chmielewski S, Kostyrko K, Wesoly J, Balint BL, Lee CK, Bluyssen HA. 2015. STAT2/IRF9 directs a prolonged ISGF3-like transcriptional response and antiviral activity in the absence of STAT1. Biochem J 466:511-524. https://doi .org/10.1042/BJ20140644.

59. Cunningham $S$, Graham $C$, Hutchinson $M$, Droogan A, O'Rourke $K$, Patterson C, McDonnell G, Hawkins S, Vandenbroeck K. 2005. Pharmacogenomics of responsiveness to interferon IFN-beta treatment in multiple sclerosis: a genetic screen of 100 type I interferon-inducible genes. Clin Pharmacol Ther 278:635-646. https://doi.org/10.1016/j.clpt.2005.08 .018.

60. Bluyssen HA, Vlietstra RJ, van der Made A, Trapman J. 1994. The interferonstimulated gene $54 \mathrm{~K}$ promoter contains two adjacent functional interferonstimulated response elements of different strength, which act synergistically for maximal interferon-alpha inducibility. Eur J Biochem 220:395-402. https://doi.org/10.1111/j.1432-1033.1994.tb18636.x.

61. Begitt A, Droescher M, Meyer T, Schmid CD, Baker M, Antunes F, Knobeloch KP, Owen MR, Naumann R, Decker T, Vinkemeier U. 2014. STAT1cooperative DNA binding distinguishes type 1 from type 2 interferon signaling. Nat Immunol 15:168-176. https://doi.org/10.1038/ni.2794.

62. Sugai A, Sato H, Yoneda M, Kai C. 2017. Gene end-like sequences within the $3^{\prime}$ non-coding region of the Nipah virus genome attenuate viral gene transcription. Virology 508:36-44. https://doi.org/10.1016/j.virol .2017.05.004.

63. Rima BK, Duprex WP. 2009. The measles virus replication cycle. Curr Top Microbiol Immunol 329:77-102.

64. Plumet S, Duprex WP, Gerlier D. 2005. Dynamics of viral RNA synthesis during measles virus infection. J Virol 79:6900-6908. https://doi.org/10 .1128/JVI.79.11.6900-6908.2005.

65. Ray J, Fujinami RS. 1987. Characterization of in vitro transcription and transcriptional products of measles virus. J Virol 61:3381-3387.

66. Gluzman Y. 1981. SV40-transformed simian cells support the replication of early SV40 mutants. Cell 23:175-182. https://doi.org/10.1016/0092 $-8674(81) 90282-8$

67. Hagiwara K, Sato $H$, Inoue $Y$, Watanabe A, Yoneda M, Ikeda F, Fujita K, Fukuda H, Takamura C, Kozuka-Hata H, Oyama M, Sugano S, Ohmi S, Kai C. 2008. Phosphorylation of measles virus nucleoprotein upregulates the transcriptional activity of minigenomic RNA. Proteomics 8:1871-1879. https://doi.org/10.1002/pmic.200701051.

68. Hino K, Sato H, Sugai A, Kato M, Yoneda M, Kai C. 2013. Downregulation of Nipah virus $N$ mRNA occurs through interaction between its $3^{\prime}$ untranslated region and hnRNP D. J Virol 87:6582-6588. https://doi.org/ 10.1128/JVI.02495-12.

69. Sugai A, Sato H, Yoneda M, Kai C. 2013. Phosphorylation of measles virus nucleoprotein affects viral growth by changing gene expression and genomic RNA stability. J Virol 87:11684-11692. https://doi.org/10.1128/ JVI.01201-13.

70. Sugai A, Sato H, Yoneda M, Kai C. 2012. Phosphorylation of measles virus phosphoprotein at S86 and/or S151 downregulates viral transcriptional activity. FEBS Lett 586:3900-3907. https://doi.org/10.1016/j.febslet.2012 .09 .021 .

71. Yoneda M, Guillaume V, Sato H, Fujita K, Georges-Courbot MC, Ikeda F, Omi M, Muto-Terao Y, Wild TF, Kai C. 2010. The nonstructural proteins of Nipah virus play a key role in pathogenicity in experimentally infected animals. PLoS One 5:e12709. https://doi.org/10.1371/journal.pone .0012709 .

72. Niwa H, Yamamura K, Miyazaki J. 1991. Efficient selection for highexpression transfectants with a novel eukaryotic vector. Gene 108: 193-199. https://doi.org/10.1016/0378-1119(91)90434-D. 